Which Way to Least

-Cost Energy Services?

\title{
A Close Look At Eigth Great Energy Myths With \\ Particular Attention to the \\ Generation and Use \\ of Electricity
}

May 1982

DO NOT MICROFILM

COVER

\section{U.S. Department of Energy}

Office of Policy, Planning and Analysis

Divisior, of Electric Utilities

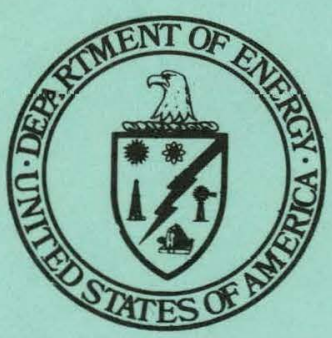




\section{DISCLAIMER}

This report was prepared as an account of work sponsored by an agency of the United States Government. Neither the United States Government nor any agency Thereof, nor any of their employees, makes any warranty, express or implied, or assumes any legal liability or responsibility for the accuracy, completeness, or usefulness of any information, apparatus, product, or process disclosed, or represents that its use would not infringe privately owned rights. Reference herein to any specific commercial product, process, or service by trade name, trademark, manufacturer, or otherwise does not necessarily constitute or imply its endorsement, recommendation, or favoring by the United States Government or any agency thereof. The views and opinions of authors expressed herein do not necessarily state or reflect those of the United States Government or any agency thereof. 


\section{DISCLAIMER}

Portions of this document may be illegible in electronic image products. Images are produced from the best available original document. 
This report has been reproduced directly from the best available copy.

Available from the National Technical Information Service, U. S. Department of Commerce, Springfield Virginia 22161.

Price: Printed Copy A03

Microfiche A01

Codes are used for pricing all publications. The code is determined by the number of pages in th publication. Information pertaining to the pricing codes can be found in the current issues of the followin publications, which are generally available in most libraries: Energy Research Abstracts, (ERA) Government Reports Announcements and Index (GRA and I); Scientific and Technical Abstract Report (STAR); and publication, NTIS-PR-360 available from (NTIS) at the above address. 
Which Way to Least -Cost Energy Services?

$\mathrm{DOE} / \mathrm{PE}--0044$

DE82 021118

\section{A Close Look At Eigth Great Energy Myths With Particular Attention to the Generation and Use of Electricity}

May 1982

$\checkmark$ U.S. Department of Energy

$\checkmark$ Office of Policy, Planning and Analysis Division of Electric Utilities Washington D.C. 20585

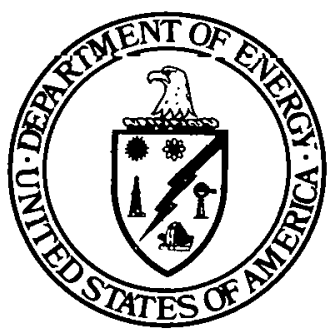


A CLOSE LOOK AT EIGHT GREAT ENERGY MYTHS, WITH PARTICULAR ATTENTION TO THE GENERATION AND USE OF ELECTRICITY

\section{Introduction}

- In recent years the generation and interpretation of energy supply and demand projections has become a fundamental element of most energy policy discussions. The range and diversity of these projections is enormous. They vary widely in terms of purpose, breadth, level of detail, time horizon, method--and above all, results.

Some of the most talked-about pieces in the current literature are those published by Roger Sant and his colleagues at the Energy Productivity Center (EPC), particularly The Least-Cost Energy Strategy (1979) l/ and Eight Great Energy Myths (1981).2f They have attracted this attention for several reasons. First, they have had comparatively little competition, in that there have been few non-Federal attempts to prepare national projections of demand based on models of end-user decisionmaking.

EPC has not, however, simply produced dry tomes which differ from other analyses primarily by focusing upon the demand side, rather than the supply side of the energy equation. In part, EPC's demand projections for 1990 and 2000 have attracted attention because they are dramatically lower than those produced by DOE's Energy Information Administration (EIA). The disparity is even more striking when one learns that EPC used EIA's energy price projections (and energy supply costs), and assumed no reduction per capita in the level of energy services (e.g., space conditioning, transportation of

1/Sant, Roger W., et al, The Least-Cost Energy Strategy: Minimizing Consumer Costs Through Competition (EPC/Mellon Institute, Arlington, VA, 1979). Also, see Steven C. Carhart, et al, The Least Cost Energy Strategy: Technical Appendix (EPC/Mellon Institute, Arlington VA, 1979).

2/Sant, Roger W., et al, Eight Great Energy Myths: The Least-Cost Energy Strategy, $1978-2000$ (EPC/Mellon Institute, Arlington VA, 1981). 
people and commodities) supplied to the economy. EPC's central themes are that such reductions can occur through wider deployment of existing energy-efficient technologies, and that such deployment will occur as a natural result of economic forces if fuels are priced at their real value and if governments refrain from actions which bias users' selection of fuel/technology combinations to meet energy service requirements.

Other reasons for the prominence of these works are that they have been produced in small, easily-read volumes, and they have been written in an attention-getting style. Myths is appropriately titled; the authors believe that much of today's conventional wisdom about energy is erroneous. On the financial health of the electric utilities, for example, they contend that "To say that you can solve utilities' problems by raising rates is much like saying we could solve the problems of Chrysler by raising the price of their automobiles."피

EPC's critics have attacked its conceptual framework, its enengy mudeling efforts, the credibility of its projections, and EPC's interpretation of the significance of its projections. These criticisms will be discussed in due course below. Regardless of where one stands on them, however, Sant. and hi.s colleagues have made several important contributions to our understanding of energy affairs:

(1) They have made it abundantly clear that most end-users have little use for energy per se. The great majority of users are interested in services which have an energy or fuel component, such as space heating and cooling, mechanical drive, process heat, transportation, etc.

(2) They have driven home the point that most energy service requirements can be met through various combinations of capital equipment, fuel, and operating and maintenance costs. Moreover, the comparative cost of these options is apt to vary considerably, in both the short term and the long term. In the short term, some technology/fuel combinations will be more efficient economically than others as a means of meeting service requirements, and they will tend to dominate the market. Over the long term, however, the ranking of options is more changeable, given shifts in the prices of fuels or materials and the emergence of new technologies.

(3) Finally, they have underscored the importance of achieving a better understanding of both the processes and results of end-user decisions. Econumic theury telis us that over time, the cumulative result of these decisions will be a collective preference for the most economically efficient solutions to service requirements. To make

3/Myths, p. 36 . 
reliable demand projections, however, one must be both specific and accurate about the future $\mathrm{mix}$ of service requirements, limitations upon users' capacities to make rapid adjustments, the characteristics of the existing capital stock, and the comparative costs of competing technological options.

The basic purpose of this paper is to assess Myths' implications for the generation and use of electricity. EPC's projections will be compared with others prepared by the Energy Information Administration, DOE's Office of Policy, Planning and Analysis, and Energy and Environmental Analysis,. Inc. Major differences in method, inputs, and results will be identified, and to the extent possible, explained. In keeping with the focus on electricity, comparatively little attention will be given to the transportation sector.

The remainder of the paper is organized as follows: Section II is a general summary of the review, and presents EPC's principal assumptions, methods, results, etc., along with this reviewer's major conclusions. Sections III, IV and $V$ provide more detail for readers who wish to trace the analysis more closely. Section III, for example discusses some fundamental criticisms of EPC's conceptual approach. Section IV, in contrast, accepts EPC's basic framework as a given, and raises certain criticisms of EPC's analysis within that framework. Section $V$ discusses the treatment of electric generation in Myths, and probes the implications of EPC's results.

\section{Summary}

Myths consists of two principal components: (1) The presentation and interpretation of EPC's energy demand projections; and (2) a critical review of what EPC perceives as today's conventional wisdom about energy. (The "eight myths" of the title are seen as tenets of the conventional wisdom.) The demand modeling component is the more important of the two, and it will be dealt with here first.

Briefly, EPC contends that a systematic application of a least-cost approach to the satisfaction of energy service requirements yields total end-use energy demand projections for 1990 and 2000 substantially below those developed by the Energy Information Administration (EIA). (See Table 1 for a comparison of EPC's projections with those published by EIA in ARC/794/; this comparison is particularly relevant because EPC used EIA's ARC/79 fuel price projections in its calculation of least-cost solutions to energy service requirements.) The implications are that either we are not as market-oriented in our end-use decisions as we think, or more conventional projections are faulty, or both.

4/Energy Information Administration, Annual Report to Congress, 1979, III, Projections, DOE/EIA-0173(79)/3. 
Second, EPC asserts that the low energy demand figures shown in Table 1 are achievable with no reduction in the level of energy services provided (in relation to general economic activity) and with little or no increase in the user's total annual cost of energy services. As shown in Table 2, the capital component of annual energy service costs would go up, but in most cases this would be more than offset by a reduction in the fuel cost component.

Third, EPC believes that under the least-cost approach, annual growth in central-station electricity demand for the period 1978-2000 could be reduced from EIA's projected $2.6 \%$ to $0.3 \%$. 1 Although EPC's models do not address the question of whether additonal generating capacity is needed, it is evident that if demand growth drops as low as $0.3 \%$ per year, very little additional capacity is required. Completion of plants now under construction would be sufficient to both replace worn-out equipment and meet increased demand. Replacement of operational gas-fired baseload units would probably not be economic under the low gas prices assumed by EPC. Operational oil-fired plants would probably be converted to gas, or at greater expense, to coal. While electricity growth fades in EPC's projections (in comparison to EIA's), especially in the industrial sector, natural gas sales boom. In particular, EPC foresees a major expansion in gas-turbine cogeneration by industrial users, with a total installed generating capacity of approximately 50 Gwe by $2000.6 /$

EPC's figures also show oil imports declining to near-zero levels by 2000 . Throughout, EPC's results would be achieved by relying on market forces, as opposed to government programs or regulations. Large new markets are seen in the 1980's and 1990's for enterpreneurs who can aid energy users in making appropriate investments to improve the energy efficiency of their buildings and equipment. (Table 3 compares the magnitude of projected investments in energy et'iciency, investiments in energy supply develupment, and outlays for energy imports, as seen by EPC for the 1980's and 1990's.) The prospective investments in energy efficiency, EPC says, fall into three major categories: building retrofits, improved automobile fuel economy, and gas turbine cogeneration in the industrial sector. $7 /$

Should one care how EPC came to these conclusions? Yes. EPC's results sound like the solution to many energy regulatory and policy problems--and this is troubling, because EPC's projections do not hold up well under scrutiny. The difficulty does not lie with EPC's methodological approach.

5/Demand growth rates calculated from data presented in Table 5, p. 17 below.

6/Cogeneration capacity estimate calculated by the author, from EPC's projected fuel consumption figures. See p. 32, note 35, for details.

II Myths, p. 32. 
Table 1. End-Use Energy Consumption in 1990 and 2000, According To Projections by EPCa/ and EIAb/' (Quads)

Sector

\begin{tabular}{|c|c|c|c|c|c|}
\hline & $\underline{1978}$ & EPC & $\underline{E I A}$ & EPC & $\underline{E I A}$ \\
\hline Residential & 11.1 & $7.9 \underline{c} /$ & 11.0 & $7.8 \mathrm{c}^{\prime}$ & 10.8 \\
\hline Commercial & 7.7 & $5.1 \underline{c}^{\prime}$ & 7.2 & $5.8 \underline{c}^{\prime}$ & 8.2 \\
\hline Industrial & 23.2 & 29.5 & 26.8 & 34.9 & 35.8 \\
\hline Transportation & $\underline{20.9}$ & 19.1 & 19.4 & 17.9 & $\underline{24.1}$ \\
\hline Totaldg/ & 63.1 & 61.8 & 64.3 & 66.2 & 78.9 \\
\hline
\end{tabular}

Notes

a. EPC projections from Roger W. Sant, et al, Eight Great Energy Myths: The Least-Cost Energy Strategy, 1978-2000 (EPC/Melion Institute, Arlington, VA, 1981), pp. 11, 14-15. EPC used the same price projections as EIA, but it did not re-equilibrate prices after making assumptions which reduced demand significantly in most sectors.

b. Energy Information Administration, Annual Report to Congress, 1979, v. III, Projections (DOE/EIA-0173(79)/3, Washington, D.C., $\frac{19790)}{1980}$.

c. EPC's published projections combine residential and commercial usage into a single "buildings" sector. Here EPC's projected consumption in "buildings" has been divided provisionally into residential and commercial components according to the proportions projected by EIA.

d. Totals do not always sum because of rounding errors. 
Table 2. Maçnitude and Composition of Annual Energy Service

Cjsts Per Capita as Projected by EPC Using Least-Cost Strategy (1979\$ and Percent of Total Cost)

\begin{tabular}{|c|c|c|c|c|c|c|c|c|c|c|c|c|c|c|c|c|c|c|}
\hline \multirow{3}{*}{ COMPONENT } & \multicolumn{6}{|c|}{ RESIDENTIAL \& COMMERCIAL ELDGS. } & \multicolumn{6}{|c|}{ TRANSPORTATION } & \multicolumn{6}{|c|}{ INDUSTRIAL } \\
\hline & \multicolumn{2}{|c|}{1978} & \multicolumn{2}{|c|}{1990} & \multicolumn{2}{|c|}{2030} & \multicolumn{2}{|c|}{1978} & \multicolumn{2}{|c|}{1990} & \multicolumn{2}{|c|}{2000} & \multicolumn{2}{|c|}{1978} & \multicolumn{2}{|c|}{1990} & \multicolumn{2}{|c|}{2000} \\
\hline & $\$$ & $\%$ & $\$$ & $\not{x}$ & $\$$ & $\%$ & $\$$ & $\mathscr{6}$ & $\$$ & $\%$ & $\$$ & $\%$ & $\$$ & 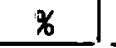 & $\$$ & $\%$ & $\$$ & $\%$ \\
\hline $\begin{array}{l}\text { Capital \& } \\
\text { Maintenanceal }\end{array}$ & 600 & 50.5 & $7 \div 2$ & 64.81 & 755 & 67.1 & 555 & $42.2^{1}$ & 657 & 51.3 & 703 & 58.6 & 345 & 45.8 & 384 & 47.01 & 402 & 50.4 \\
\hline Fuel & 589 & 49.5 & 386 & 35.2 & 3.1 & 32.9 & 759 & 57.8 & 623 & 48.7 & 497 & 41.4 & 408 & 54.21 & 433 & 53.0 & 396 & 49.6 \\
\hline
\end{tabular}

a. Cost of capital assumed by EPC is 5 percent real per annum in all sectors.

Source: Myths, pp. 24-27. 
Table 3. EPC's Projections of Total Annual Energy Efficiency Investments, Annual Energy Supply Investments, and Total Annual cost of Oil Imports (Bilions of $1979 \$$ )

Type of Expenditure

Energy Efficiency Investments

$$
\text { Buildings }
$$

Industry

Transportation

Energy Supply Investments

Oil and Gas Development

Electric Utilities

Coal and Nuclear Fuel Dev't

$0 i 1$ Imports

Total

Percent of Projected

Annual GNP

\section{Estimated 1980음}

1980 's

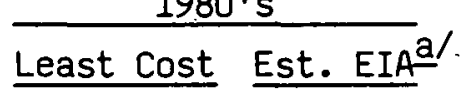

1990 's

Least Cost. Est. EIA

\section{0}

11

22

42

18

40

22

14

26
22

19

49

73

212

59

67

227

31

216

10

241

8

6

7

Source: Myths, pp. 32, 49.

a. Figures for 1980 and EIA cases calculated by EPC using EIA data. 
Although their approach has some significant weaknesses, such as a failure to use equilibrium prices, these flaws are not obviously fatal. The problem lies instead with EPC's implementation, and in particular, with the use of estimates of future oil and gas prices which are too low and with some overly optimistic assumptions concerning the pace at which energy users will invest in energy efficiency improvements. As a consequence, EPC's projections appear pertinent only to a narrow and not very probable range of possible futures.

Because EPC used energy price projections developed by EIA in 1979 for an analysis published in 1981, all of their energy price assumptions are somewhat out of date. This can be seen clearly in Table 4, which compares EIA's ARC/79 and ARC/81 projections of fuel prices to end-users in 1990. Table 4 shows that EIA now expects gas in 1990 to cost 21-59\% more in real terms than estimated in 1970, with the increases being largest in the residential and commercial sectors. Similarly, 31-43\% higher prices are now forecast for petroleum products, although the inter-sectoral variance is smaller than in the case of gas. Projected electricity prices, in contrast, have been reduced by about $2-3 \%$ in all sectors. Thus, if EPC's models were re-run with EIA's ARC/81 prices and no other changes, the effects (in comparison with EPC's current results) would be additional investments in energy efficiency by oil and gas users, reduced demand for those fuels, and some increase in electricity usage, in preference to oil and gas.

However, as noted above, EPC's current results are heavily dependent upon over-optimistic assumptions about the future pace of investment in energy efficiency. First, EPC assumed that the real cost of investment capital for all sectors was $5 \%$ per year. This figure is reasonable, although it would have been preferable to specify a range and test the sensitivity of the overall results to alternative figures. ' Further, EPC also assumed that energy users have ample access to capital at this rate, and that where energy-efficiency investments are cost-effective, they are made.

These latter assumptions are at odds with ample empirical evidence that energy users' real implicit discount rates, or hurdle rates, in all sectors are generally much higher than 5\%. Consumers' implicit discount rates have been estimated at 10-25\% for energy improvements to residences and 40-60\% for investments in more efficient appliances and automobiles. In the commercial and industrial sectors, hurdle rates for investment projects vary widely depending upon the type of business and the type of investment, but rates in the $20-30 \%$ range are common for investments which are not designed 
Table 4. Comparison of EIA Projections of Fuel Prices to End-Users in 1990, From ARC/79, and ARC/81 $\underline{\text { b/ }}$ (All prices in $1979 \$ / M M B t u$ )

\begin{tabular}{|c|c|c|c|c|c|c|c|c|c|}
\hline \multirow[b]{2}{*}{ Fuel } & \multicolumn{3}{|c|}{ Residential } & \multicolumn{3}{|c|}{ Commercial } & \multicolumn{3}{|c|}{ Industrial } \\
\hline & ARC/79 & ARC/81 & * Change & ARC/79 & ARC/.81 & \% Change & ARC/79 & ARC/81 & * Change \\
\hline Natural Gas & 4.65 & 6.82 & +46.7 & 4.19 & 6.66 & +58.9 & 4.85 & 5.87 & +21.0 \\
\hline Distillates & 7.50 & 9.82 & +30.9 & 7.16 & 9.50 & +32.7 & 7.18 & 9.31 & +29.7 \\
\hline Residual Oil & -- & - & -- & 6.24 & 8.17 & +42.6 & 6.22 & 8.17 & +31.4 \\
\hline Coal. & -- & -- & -- & -- & -- & -- & 2.26 & 2.20 & -2.7 \\
\hline Electricity & 16.56 & 16.24 & -1.9 & 16.92 & 16.36 & -3.3 & 12.18 & 11.75 & -3.5 \\
\hline
\end{tabular}

$\underline{\text { Notes }}$

a. Energy Information Administration, Annual Report to Congress, 1979, v. III, Projections (Washington, D.C., DOE/EIA-O173(79)/3.

b. Energy Information Administration, 1981 fnnual Report to Congress, v. III, Energy Projections (Washington, D.C., DOE/EIA-0173(81)/3). 
to increase the company's sales or market share. Most investments in improved energy efficiency would probably fall into this category.

Accordingly, if EPC's models were re-run with a more realistic portrayal of energy users' investment behavior, as well as more up-to-date fuel price projections, it is probable that their results would be much less dramatic. In particular, despite higher oil and gas prices, investments in energy efficiency would probably be smaller, demand for electricity and other fuels would grow at more conventional rates, gas-fired cogeneration would cease to be economic, and the projected substitution of gas for electricity in some sectors would probably be reversed.

lurning now to EPC's attack upon conventional energy wisdom, the eight "myths" are presented below, along with EPC's counter-arguments and some brief comiments.

1. "Energy is ecarce" and growing scarcer; there is a risk of drastic shortages ahead. EFC's counterposition is that although real prices for energy have gone up (and will continue to go up), the combination of improved end-use efficiency and alternative supply devclopment will preclude drastic shortages. This "myth," along with EPC's rejoinder, has a rather contrived quality. Strictly speaking, energy is indeed "scarce" -- as is any other commodity of economic value, and rising prices, relative to other commodities, reflect an increasing scarcity. At the same time, the view that we have many energy alternatives, albeit at higher prices, is widely held.

2. "Energy cost increases will only get worse". EPC's view is that although fuel prices will rise, the total cost of energy services (per capita) can be held level or perhaps even reduced through appropriate investments to improve the efficiency of fuel use. EPC is, at best, partially correct. If energy prices rise, energy service costs will increase, unless appropriate investments are made. Whether such investments are likely to be made is a question EPC has dealt with in Myths only by assumption. Technically, even if optimal investments are made, future energy service costs could rise, stay level, or decline depending upon the cost of capital, the magnitude of energy price changes, and the degree to which current energy use is suboptimal.

8/Concerning implicit real discount rates for residential improvements and appliance efficiency, see Residential Energy Decisionmaking: An Overview with Emphasis on Individual Discount Rates and Responsiveness to Household Income and Prices (Columbia MD: Hittman Aseociates, Inc., August 1981), pp. I-I, I-3. On implicit real discount rates for automobile efficiency improvements cf. "Automotive Consumer Response to Fuel Economy Information and Technology, "Draft Report, Subtask IV of Task 11, DOE Contract \#DC-ACO1-PE79-70032 (J.D. Power \& Associates, January 1982). For a typical discussion of the factors included in corporate assessments of energy retrofit projects, see "Reaganomics Blamed for Delays in Coal Conversions", Energy User News, March 8, 1982, p. 17. 
3. "The environmentalists are causing the problem." EPC did not attempt to address environmental issues in any detail in their modeling. They did, however, require compliance by competing technologies with Federal environmental standards as established in June 1981. Compliance with these requirements did not prevent the emergence of major fuel economy improvements and large increases in coal consumption by industry as least-cost solutions to energy service requirements. Without endorsing the current standards and requirements substantively, EPC concludes that they are not a barrier to meeting energy service demands at reasonable cost. This appears to be a reasonable interpretation.

4. "We cannot conserve our way to economic growth." EPC contends that on the contrary, energy efficiency investments contribute to growth, because they are frequently highly cost-effective (and thus release economic resources for other productive uses) while maintaining a high level of energy services in the economy. EPC's view is directionally correct, but as shown below, 9 they overstate their case. Their assumption that 1978 service levels must be met tends to overstate both the size of future markets for energy-efficiency technologies, and the aggregate significance of energy-efficiency investments.

5. "Imports are the [core of the energy] problem." EPC's argument is that imported oil is no longer competitive in most markets with alternative fuels. Even in the transportation sector, where substitutes are more limited, the opportunity for fuel economy improvements is sufficiently large and attractive economically to enable major demand reductions. Accordingly, EPC asserts that oil imports can be reduced to a very low level by 1990 . This view is plausible, but EPC has not presented a persuasive case. The core issue is whether the multitudinous investments and adjustments required can be made in so short a time, and in Myths EPC has not addressed itself to the transition process.

6. "The generation of electricity is a natural monopoly." EPC holds that the era in which generation of electricity was dominated economically by large centralized generating units is coming to an end. They see gas turbine cogeneration as the least-cost approach to energy services in parts of the industrial sector. Although most decentralized systems (based on photovoltaics, wind, mini-sized hydro units, biomass, fuel cells, etc.) are not yet competitive with conventional generation, their costs are declining. EPC believes that deregulation of the generation portion of the system -- but not distribution -- may be desirable and should be explored thoroughly. Here, one has to say that EPC (whose stated position is very cautious) has been overtaken by events. Virtually all concerned parties have now declared an affirmative interest in at least studying some form of deregulation. 
7. "Fuel for cars is the problem." This item is a close relative of \#5, and EPC's response is much the same -- namely, that more efficient use of petroleum derivatives in all sectors will release additional fuel for the transportation sector, and the cost of synthetic liquid fuels from oil shale and methanol may decline sufficiently in the years ahead to make them competitive with conventional gasoline and diesel fuels. Thus EPC asserts that the transportation sector is no more problematic than other major sectors of the economy. Here, as in \#5, EPC's view is plausible but not persuasive. According to EPC's own analysis, to hold down both transportation service costs and fuel consumption, consumers must be willing to make substantial front-end investments in very fuel-efficient vehir.ses, and EPC. does not attempt in Myths to analyze the implied shift in behavior.

8. "Deregulated gas will rise to the price of oil." "The conventional view is that gas is a potential substitute for petroleum-based fuels in many uses. EPC, however, sees petroleum-based fuels being driven out of most markets save transpnrtation because they are not competitive. Accordingly, deregulated gas prices will not rise to these levels. Rather, the price of gas will be determined principally by the price of coal and electricity in competition in stationary markets. EPC's argument has some conceptual appeal, but the fact remains that EPC has not made a serious effort to determine where deregulated gas prices would stabilize. Instead, they have used some outdated EIA prices to which EIA no longer subscribes. While gas prices may not rise to the level of petroleum derivatives, it is not very plausible that they will remain as low as EPC has assumed.

In sum, EPC's "myths" material is engagingly written, but as with their energy demand projections, it does not stand up well under scrutiny.

\section{Fundamental Criticisms of EPC's Approach}

First, although it is not a "fundamental criticism," it is important to note that EPC modeled only end-use decisions in the buildings, industrial, and transportation sectors. This results in some fundamental limitations to the analysis--i.e., although EPC is able to project end-use fuel requirements, it is essentially silent about how those fuels would be produced. This is especially important in relation to electricity. EPC projects total $\mathrm{kwh}$ demanded from utilities, but it does not address fuel use by utilities, the need for additional generating capacity, or other issues related to the satisfaction of electricity demand at least cost.

Perhaps the most important fundamental criticism concerns EPC's assumptions about energy users' investment behavior. EPC assumed a real cost of capital for all sectors of $5 \%$ per year. This is a reasonable figure, although it 
would have been preferable to specify a range and test the sensitivity of the overall results to alternative figures. However, EPC also assumed that all users have access to capital at this rate, and that where energy-efficiency investments are cost-effective, they will be made.

As noted in an earlier section, these latter assumptions conflict with empirical evidence showing that users' real implicit discount rates or hurdle rates are generally much higher than 5\%. EPC did not address this disparity in Myths, and hence one could readily interpret them as believing that users' energy investment behavior is changing dramatically. Contributors to Myths reviewed an earlier draft of this paper and rejected this interpretation strongly, on the basis of two arguments.

First, they emphasize that the projections in Myths are "presented not as a forecast of what will happen, but rather to demonstrate what is possible if known energy technology is applied on the basis of economic self-

interest". Io/ Hence, they hold that it is simply inappropriate to interpret or criticize such projections as if they were intended to be forecasts. Second, they acknowledge the disparities between user behavior and a 5\% real capital cost rate, but they contend that such differences create attractive areas of opportunity for enterpreneurs, who will raise the capital needed for the investments, and design and install them in return for a share of the fuel savings involved. This approach was elaborated in two EPC studies published prior to Myths. Il/

These arguments are not very satisfying. If Myths' projections are not to be understood as forecasts, why are they sturdy enough to expose more conventional views as "myths"? That is, how can EPC's case against the conventional wisdom be sound, unless they forecast either a marked change in energy users' investment behavior or the emergence of a corps of enterpreneurs who will bridge the gap between user decisionmaking and the economics of energy efficiency investments? In this writer's view, EPC is being inconsistent -- it terms its results projections but uses them as plausible forecasts. Accordingly, it appears quite legitimate to examine the plausibility of their results as forecasts, and this will be done on a sector-by-sector basis in Section III below.

10/Myths, p. 2 .

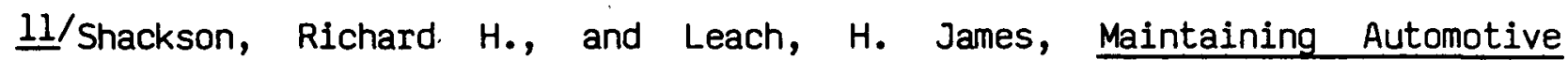
Mobility: Using Fuel Economy and Synthetic Fuels to Compete With OPEC Oil (Pittsburgh, Pa: Carnegie-Mellon Univ. Press, 1980); and Carhart, Steven C., et al., Creating New Choices: Innovative Approaches to Cut Home Heating and Cooling Costs (Pittsburgh, Pa: Carnegie-Mellon Univ. Press, 1980). 
A second fundamental criticism concerns the manner in which EPC used EIA's ARC/79 mid-price forecast. EIA developed and used these fuel prices as equilibrium prices. EPC, however, introduced various assumptions which in most cases had the effect of driving demand down sharply. turn, would have caused fuel prices to decline (somewhat) and demand to rise (somewhat), and exactly where the new equilibrium would have settled is of course unclear. In any event, it is unrealistic to expect that sharp demand reductions would not be buffered somewhat by price reductions, so that EPC's approach tends to underestimate demand.

This difficulty could probably have been avoided, though at some increase in the overall cost of the project. EPC would have had to obtain or develop supply curves for each of the fuels involved, and it would have had to run several iterations of its models using various fuel prices, until it could identify market-clearing prices and quantities for each fuel.

A third fundamental criticism concerns EPC's assumption that energy service requirements would continue at 1978 levels (after adjusting for the growth of the economy). At first, this appears to be a conservative assumption on EPC's part, intended to dramatize the potential for reducing demand with no impairment of the amenities now enjoyed by users. Upon reflection, however, this assumption becomes problematic. The energy service levels of 1978 were established in an era of comparatively low energy prices--low, at least, in comparison to the real prices projected by EIA through 2000 . Inasmuch as energy service units (i.e., one-degree increments in thermostat settings, or hundreds of passenger-miles traveled, are not all equally valued by consumers, it is unrealistic to expect that in an era of rising energy prices users will hold energy service requirements fixed. As energy prices rise, users are likely to forego some low-valued energy service units, as opposed to either paying higher fuel bills or investing scarce capital in more fuel-efficient methods of obtaining services.13/

12/The most important example of an upward shift in fuel demand resulting from EPC's assumptions is the case of natural gas in the industrial sector, where EPC's demand figure is virtually double that projected by EIA, at no increase in price. This examole demonstrates the risks involved in not using equilibrium prices.

13/David Wood makes this point in A Review of the Energy Productivity Center's "Least Cost Strategy" Study, MIT Energy Laboratory, 1981. Wood's review focuses upon EPC's first effort, which applied the least-cost approach to 1978, but his commentary is relevant in many ways to EPC's 1978-2000 analysis. 
Myths' authors could respond by citing their arguments that energy service costs per capita will be generally lower, not higher, in $2000, \underline{14}$ as users make appropriate investments to improve the energy efficiency of their buildings and equipment. According to this view, there is no reason to assume a decline in energy service demand; it might well increase. The problem here is that EPC has simply postulated that the rate of such investments will be high and that energy usage patterns will approach optimal efficiencies. If less rigorously optimistic assumptions were used, the long-term trend for the cost of energy services would probably be upward.

As argued above, rising costs for energy services will cause demand for such services to decline; this relationship is not captured by EPC's models. In principle, there is no reason why this feature cannot be incorporated into end-use models. (Some of EIA's models, in fact, have been so structured for several years.) However, it certainly adds to their complexity and requires a large data base on user-decisionmaking. Ironically, the effect of the formulation used by EPC is not to overstate or understate the extent of demand reduction, but rather to distort somewhat the means by which it is to be obtained. In particular, EPC's approach tends to overstate the size of the market for energy-efficient technologies, because future energy service requirements are overestimated.

To put this last point more generally, EPC's "least-cost" approach has, initially, an appealing, common-sense quality, but upon examination, it has some disturbing rigidities. EPC calculates least-cost solutions, but it affords no flexibility in the mix and level of energy service benefits to be purchased. An economically conscious user, however, would adopt a "maximum net benefits" approach, especially over the long term.15/ That is, he or she would more or less continually re-allocate disposable resources to maximize net benefits, and the benefits from energy services would have to compete with those from other goods and services. In contrast, EPC's approach constrains users in such a way that virtually the only type of adjustment they can make to higher energy prices is to invest in efficiency improvements. Not surprisingly, the results are a lot of investment and large reductions in demand.

The fundamental criticisms reviewed here are important, but they do not yield compelling answers about the usefulness of EPC's methodology and results. It is ultimately more useful to examine EPC's results within the framework of their basic assumptions, and in comparison with results achieved by others.

14/Cf. Myths, pp. 23-27.

15/cf. Wood, op.cit., pp. 8-12. 


\section{Criticisms Within the Framework of EPC's Basic Assumptions}

It is useful to begin with a detailed comparison of end-use consumption patterns in 2000, as seen by EIA, DOE's Office of Policy, Planning and Analysis (PPA) and EPC. Table 5 presents these projections of end-use demand by fuel and by sector, and also includes comparison figures for 1978 .

In comparing the projections, it is EIA's ARC/79 figures which are most directly comparable to EPC's, because EPC used fuel prices and macroeconomic input assumptions from ARC/79. Demand projections from EIA's ARC/81 forecast are also included in the table, to demonstrate how EIA's views on demand have shifted since ARC/79 was published. As compared with ARC/79, the price paths used in ARC/81 reflect the near-doubling of world oil prices in 1979, and substantially higher projected real prices for natural gas, although the gas price increases are not as large as those seen for petroleum products. Electricity price paths are generally slightly lower in ARC/81 than in ARC/79. PPA's price trajectorles, 16/ in comparison to $A R C / 81$, arc somewhat lower for oil derivatives, but higher for gas and electricity. The rate of increase, however, is substantially less for electricity than for either oil or gas. Also, PPA believes that the price of gas (delivered to the industrial user) will rise to a point slightly below that of residual oil after gas is deregulated in 1985 under the Natural Gas Policy Act, and that gas prices for other sectors will be determined in relation to the industrial price.

Although there is much variation from fuel to fuel and sector to sector, there appears to be a general pattern according to which consumption in 2000 is highest in the ARC/79 case, and lowest in the EPC çasse, with the ARC/81 and PPA projections somewhere in between. However, this apparent tendency toward convergence between EPC's results and the other two cases is illusory, because the latter assume significantly higher prices. If EPC's models were re-run with PPA prices or ARC/81 prices, large differences in projected demand would probably remappear, at least for gas and petroleum derivatives.

To understand more clearly how EPC obtained its results, it is useful to examine them by sector.

\section{Residential and Commercial Sectors}

In Myths, EPC treated residential and commercial usage as a single "buildings" sector. Here to facilitate comparisons with other projections, separate figures are provided for the two sectors, based upon unpublished information provided by EPC. As shown in Table 5, EPC estimates that energy use in residential buildings in 2000 could be reduced by about $22 \%$ below EIA's ARC/79 estimates, through appropriate investments in end-use efficiency. The analogous figure for the commercial sector is $37 \%$.

16/Energy Projections to the Year 2000 (U.S. Department of Energy, Washington, D.C.: DOE/PE-0029, July 1981), p. 3-3. 
Table 5. End Use Fuel Consumption in 2000 According to Projections by EIRa/, DOE/Pollcy, Planning and Analysis and EPC' (Quads)

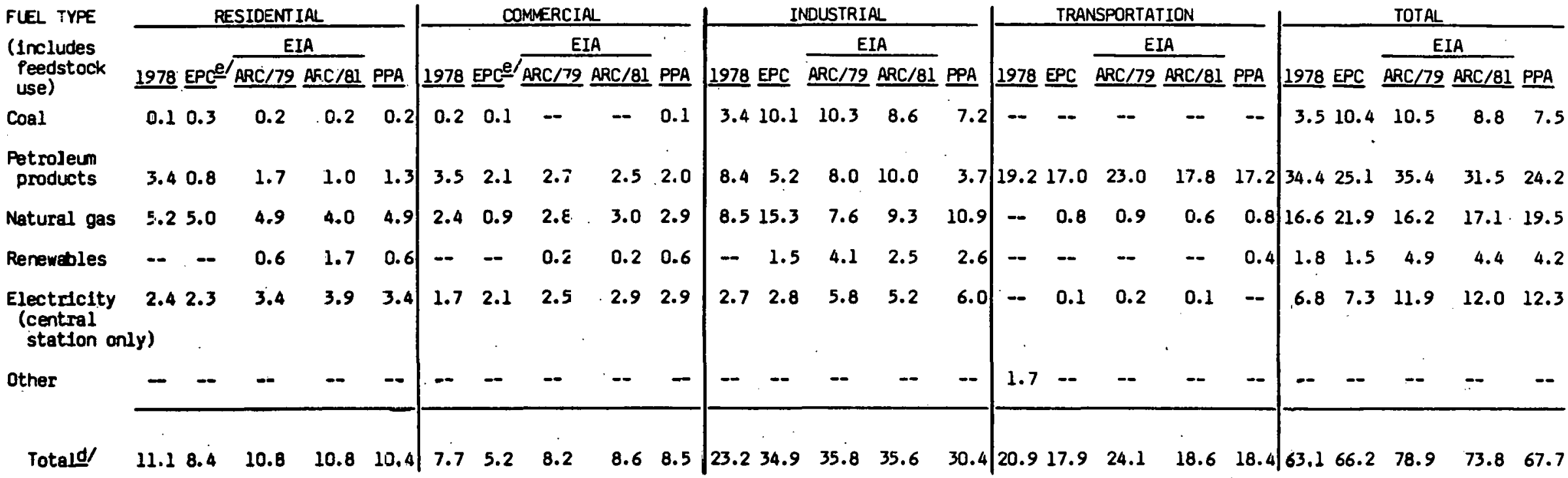

\section{Sources and Notes}

a. The Energy Enformation Adninjstration's projections are from Annual Report to Congress, 1979, v. III, Projections (D0E/EIA-0173(79)/3; and 1981 Annual Report to Congress, V. III, Eneray Projections, (DOE/EIA-0173(81)/3).

b. DoE's Oppice of Pollcy, Planning and Analysis' projections are from Eneray Projections to the Year 2000: A supplement to the National Eneray Pollcy Plan (O0E/PE-DO20), July 1981 .

c. EPC projections are from Myths.

d. Totals do not always sum due to rounding errors:

e. EPC's published materlal combines residential and compercial use into a single "bulldings" sector. Here, EPC'a projected consumption in "bulldings" is divided between. residentlal and commercial on the basis of unpublished Information provided by EPC. 
This result is obtained by using the BECOM model, $17 /$ but EPC provides no detail in Myths about the measures to be employed, their respective capital costs, type of fuel saved, etc. However, EPC sources confirm that the approach used is very similar to that employed in EPC's retrospective optimization of 1978 demand. In that analysis, total residential use was reduced by $38.1 \%$, and commercial use by $20.7 \%$, through systematic weatherization and insulation of buildings and HVAC systems. Extensive modification of HVAC equipment, lighting, and appliances was included in retrofit of both residential and commercial buildings. Fuel switching was also an option in both sectors, but had minimal effects. Investments as high as $\$ 3626 /$ household $(1981$ ) were specified for retrofit of existing single-tamily homes in northern clibites, with lower invcstments for various other housing categories.18/

The resulting average level of investment/ housirig unit was about \$1500 (1981 \$).19) For commercial buildings, BECOM was used to calculate appropriate levels of investment/ft2 for five building types in four climates. $20 /$

EPC's published materials are too fragmentary to permit a thorough assessment of their assumptions about the capital costs and economic benefits of building retrofits. It appears, however, that some of their assumptions are rather conservative. Table 6 presents EPC's 1979 assumptions and hypothetical results for retrofit of a typical north-central gas-heated home, in comparison to analogous figures develuped by ICr, Inc. in 1981.21/ EPC's estimated cost of the retrofit is much higher ( $\$ 3626$ vs. $\$ 2266$, in $1981 \$$ ), and their projected reduction in energy demand (for space heating only) is smaller (54\% vs, 71\%). The higher energy prices assumed by ICF would justify retrofitting up to a higher level of efficiency, but they would also justify a higher level of investment; this, in turn, makes the disparity in retrofit cost even more difficult to understand.

17/ Myths, p. 46 .

18/Cf. Carhart, The Least-Cost Energy Strategy: Technical Appendix, pp. 34-89.

19/In Sant, The Least-Cost Energy Strategy: Minimizing Consumer Costs Through Competition, total cost of "residential structural improvements" for the 1978 housing stock was estimated at $\$ 88.4$ billion in 1978 dollars ( $p$. 36). Assuming 73.9 million housing units in 1978 (Myths; $p .16$ ), this is about $\$ 1200$ (or $\$ 1500$ in $1981 \$$ ) per household.

20/Carhart, op.cit., pp. 56-89.

21/U.S. Housing Stock Characteristics and Economic Conservation Potential (Washington, O.C.: ICF, Inc., 1981), pp. 36-43. 
Table 6. Comparison of Input Assumptions and Hypothetical Results of Retrofit of Typical pre-1975 Gas-Heated Home in North Central U.S., According to EPC and ICF, Inc.

\begin{tabular}{|c|c|c|}
\hline & EPC Housea/ & ICF House- \\
\hline Size & $1500 \mathrm{ft}^{2}$ & $1789 \mathrm{ft}^{2}$ \\
\hline $\begin{array}{l}\text { Seasonal heating degree days } \\
\text { (HDD) }\end{array}$ & 6200 & 6419 \\
\hline Ceiling $R$ value (existing) & 11 & 9 \\
\hline 非Walls insulated & 4 (to $R-11$ ) & 3 (to $R-?$ ) \\
\hline Storm windows (existing). & 0 & $75 \%$. \\
\hline Storm doors & not specified & $100 \%$ \\
\hline $\begin{array}{l}\text { Total annual consumption, } \\
\text { pre-retrofit }\end{array}$ & $122 \times 10^{6} \mathrm{Btu}$ & not given \\
\hline $\begin{array}{l}\text { Annual consumption for } \\
\text { space heating only }\end{array}$ & $98.5 \times 10^{6} \mathrm{Btu}$ & $125.8 \times 10^{6} \mathrm{Btu}$ \\
\hline Energy prices & 1978 actual & $\begin{array}{l}\text { DOE forecasts through } \\
\text { 2000C/ }\end{array}$ \\
\hline Discount rate & $5 \%$ real & $7 \%$ real \\
\hline Retrofit cost (1981\$) & 3626 & 2266 \\
\hline $\begin{array}{l}\text { Projected reduction in house- } \\
\text { hold's annual energy demand } \\
\text { for space heating }\end{array}$ & $54 \%$ & $71 \%$ \\
\hline $\begin{array}{l}\text { Projected reduction in house- } \\
\text { hold's total annual energy } \\
\text { demand }\end{array}$ & $32 \%$ & not given \\
\hline
\end{tabular}

Sources

a. Carhart, Steven C., The Least-Cost Energy Strategy: Technical Appendix (Arlington, VA: EPC/Melion Institute, 1979), pp. 36-38.

b. U.S. Housing Stock Characteristics and Economic Conservation Potential (Washington, D.C.: ICF, Inc., 1981), pp. 36-43. ICF's primary source of data on typical residential buildings was EIA's National Interim Energy Conservation Survey (NIECS) performed during calendar years 1977 and 1978. EPC's data is somewhat older and drawn from a variety of pertinent sources.

c. ICF used DOE price forecasts titled "Preliminary National Energy Plan III," dated Feb. 20, 1981. See ICF, U.S. Housing Stock ..., Appendix 4, p. 4-2. 
There are at least two partial explanations for this disparity. One is that ICF assumed that the unretrofitted structure had an air infiltration rate of 1.0 air changes/hour (ach), and that this could be reduced to 0.6 ach at a cost of $\$ 200$ through caulking and weatherstripping. ICF expects this measure alone to reduce space heating demand by 15-20\%. In comparison, EPC included caulking and weatherstripping in its retrofit package, but apparently made no explicit assumptions about reducing infiltration. This difference is important, in that EPC's retrofitters would probably not reduce infiltration dramatically unless they set out consciously to do so (through the use of appropriate equipment, such as blower doors and infrared scanners), even if they did include weatherstripping and caulking in their efforts. On the other hand, it remains to be demonstrated cunclusively lliat ICF is realistic in assuming an initial ach of 1.0 and that a level of 0.6 ach can generally be achieved at a cost of $\$ 200$. The second explanation is that ICF included indoor thermal shutters as a retrofit option, and their model (ICON) invariably selected them in preference to the more costly and less effective storm windows. EPC did not include shutters and relied instead upon storm windows as the principal means of improving the thermal efticiency of windows. (Ironically, it appears that few homieuwliers tuday are choosing thermal shutters, despite their favorable economics; presumably they find the designs developed thus far too cumbersome or unsightly, at least in retrofit applications.)

Some elements of EPC's argument are unassailable: i.e., to achieve economic efficiency, the bulk of the nation's buildings need (further) retrofits, in response to recent and projected energy price increases; and further, if capital in the range of $\$ 1500 /$ housing unit were invested in the most cost-effective manner, substantial reductions in energy demand would indeed result.2/ Beyond this point, however, many uncertainties arise.

22/A major 1980 DOE publication found that

[IL] is pussible to achieve substantial improvements in the energy efficiency of typical residences with cost-effective investments ranging up to $\$ 1,000$ to $\$ 2,000$. Moreover, some of the houses retrofitted in fleld studies were already nominally "well-insulated" -- equipped with such features as double glazing, ceiling insulation, and wall insulation. Reductions in annual fuel use for space heating in the range of 40 percent appear available with no loss in comfort, and much larger reductions appear technically feasible. Simllar potential appears to exist for other uses of energy in buildings.

(Reducing U.S. Oil Vulnerability, U.S. Department of Energy, November 1980 , DOE/PE-0021, p. V-F-1. Sources cited include Marc H. Ross and Robert $\mathrm{H}$. Williams, Drilling for $\mathrm{Oil}$ and Gas in our Buildings (Princeton, N.J.: Princeton University Center for Environmental Studies, Report PU/CEES 87, July 1979), and Residential Energy Efficiency Standards Study (National Institute of Building Sciences, February 1980)). 
For example, Myths' authors might argue that recent statistics documenting declining energy consumption per household support their conclusions. Such an interpretation would have several weaknesses. Despite obvious indications of significant retrofit activity (such as sales of storm windows and insulation materials to non-builders) it is unclear how much of the reduction in demand should be attributed to improved efficiency through retrofit and how much to outright reduction in demand for energy services. The available evidence (summarized graphically in Figure 1 and in tabular form in Table 7) suggests that reduced residential demand should not be attributed primarily to retrofits. For example, analysts at Oak Ridge National Laboratory, using EIA data, found that in 1977-78 more than half of U.S. households took no retrofit action of any kind.23/ Similarly, IRS data show that only $7.8 \%$ of all households took advantage of the tax credit for residential conservation measures in 1978; the comparable figure for 1979 was 6.1\%. The average investment claimed by these taxpayers, moreover, was only about $\$ 700 . \underline{24 \text { l }}$

The plain fact is that our analytical tools in this area are still rather crude. Despite pioneering efforts by EIA in developing survey data on energy use in residential (and commercial) buildings, there are no reliable baselines describing the existing housing stock in terms of typical (pre-retrofit) ach levels, effective R-values, etc. Even if one could develop an empirically-based retrofit rate ( $x \%$ of the housing stock retrofitted annually, at an average cost of $y$ ), one would still need to determine empirically the effectiveness of these investments in reducing energy consumption. That is, some fraction of retrofits are likely to be poorly designed or installed, and to some extent efficiency improvements may be offset by changes in consumer behavior (e.g., higher thermostat settings in winter).

This skepticism about the extent and effectiveness of current retrofit activities leads ultimately to the central weakness of EPC's projections for the buildings sector, which is the assumption that building owners, aided perhaps by enterpreneurs, will bring their energy investment behavior into approximate alignment with the real cost of capital. The evidence of such behavioral shifts is slight, and the economic viability of the sharedsavings approach to retrofits in the residential and small commercial user markets remains to be confirmed.

23/Hirst, Eric, et al., Improving Energy Efficiency: The Effectiveness of Government Action (Energy Division, Oak Ridge National Laboratory, March 1981), p. 12 .

24/Unpublished data obtained by DOE from the Internal Revenue Service. 


\section{Energy Trends in Residential Buildings}

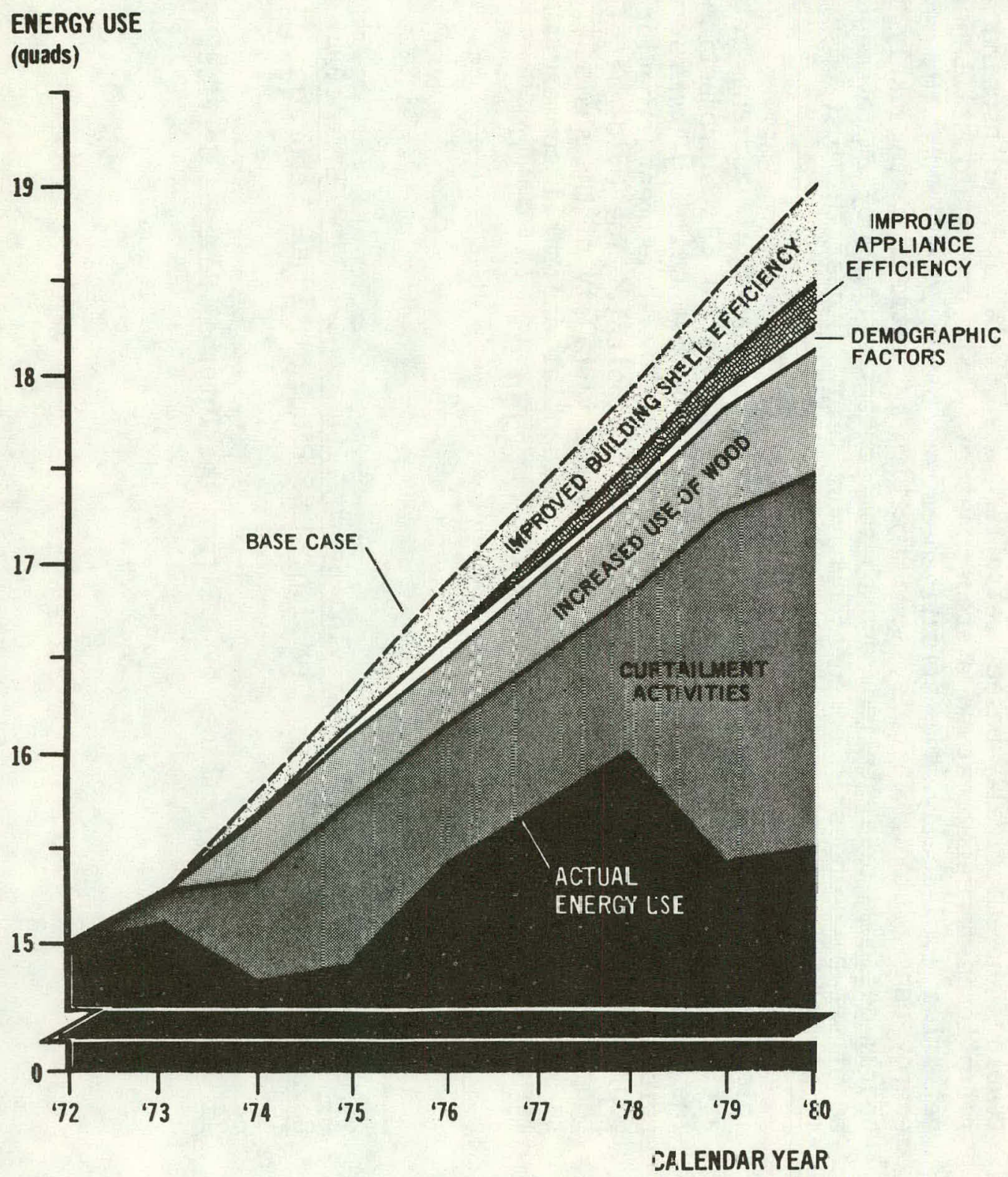

- ENERGY USE in 1980 savings was down 3.5 quads from the base case.

- These ENERGY SAVINGS (18\%) result from several factors:

- IMPROVED BUILDING SHELL EFFICIENCY (0.5 quads) -- achieved by retrofitting old homes with conservation measures such as insulation, storm doors, caulking, and weatherstripping; and building more energy efficient new homes;

- IMPROVED APPLIANCE EFFICIENCY (0.2 quads.) -- achieved by replacing old appliances with more efficient models; and installing energy efficient models in new homes;

- DEMOGRAPHIC FACTORS (0.1 quad)-migration from colder to warmer climates; and shifts to smaller household units;

- INCREASED USE OF WOOD (0.7 quad) -- as a substitute for conventional home-heating fuels;

- CURTAILMENT ACTIVITIES (2.0 quads) -including temperature setbacks, room shutoffs, and reduced appliance use.

Source: A. Gravitz, Office of Policy, Planning and Analysis, U.S. Department of Energy Energy use data fron State Energy Data Report DOE. EIA, September 1981 Build ng shell and appliance efficiency data from "An Analysis of Changes in Resicential Energy Consumption, 1973-1980," Draft report, March 1982. Pacific Northwest Laborato-ies. Demographic factors data from Annual Housing Survey, Burecu of the Censis . Wood use data form "Alternative Energy Data Summary for the Lnited States," Resource and Techrology Vanagement Corporation. 1981 . 
Table 7. ENERGY TRENDS IN RESIDENTIAL BUILDINGS

(Energy Use in Quads)

\begin{tabular}{|c|c|c|c|c|c|c|}
\hline Year & $\begin{array}{c}\text { Base } \\
\text { Case } \\
\text { A }\end{array}$ & $\begin{array}{l}\text { Adjusted } \\
\text { for } \\
\text { Improved } \\
\text { Bullding } \\
\text { Shell } \\
\text { Efficlency } \\
\text { B }\end{array}$ & $\begin{array}{l}\text { Adjusted } \\
\text { Por } \\
\text { Improved } \\
\text { Appliance } \\
\text { Efficiency. } \\
\text { C }\end{array}$ & $\begin{array}{l}\text { Adjusted } \\
\text { for } \\
\text { Demographic } \\
\text { Factors } \\
D\end{array}$ & $\begin{array}{l}\text { Adjusted } \\
\text { for } \\
\text { Increased } \\
\text { Use of } \\
\text { wood } \\
\text { E }\end{array}$ & $\begin{array}{l}\text { Adjusted } \\
\text { for } \\
\text { curtailment } \\
\text { Activities } \\
F\end{array}$ \\
\hline $\begin{array}{l}72 \\
73 \\
74 \\
75 \\
76 \\
77 \\
78 \\
79 \\
80\end{array}$ & $\begin{array}{l}15.00 \\
15.30 \\
15.80 \\
16.30 \\
16.90 \\
17.40 \\
17.90 \\
18.50 \\
19.00\end{array}$ & $\begin{array}{l}15.00 \\
15.30 \\
15.68 \\
16.14 \\
16.61 \\
17.05 \\
17.51 \\
18.08 \\
18.49\end{array}$ & $\begin{array}{l}15.00 \\
15.30 \\
15.66 \\
16.14 \\
16.60 \\
17.00 \\
17.42 \\
17.92 \\
18.25\end{array}$ & $\begin{array}{l}15.00 \\
15.30 \\
15.66 \\
16.11 \\
16.56 \\
18.94 \\
17.35 \\
17.86 \\
18.17\end{array}$ & $\begin{array}{l}15.00 \\
15.30 \\
15.36 \\
15.74 \\
16.15 \\
16.49 \\
16.85 \\
17.30 \\
17.52\end{array}$ & $\begin{array}{l}15.00 \\
15.10 \\
14.80 \\
14.90 \\
15.40 \\
15.70 \\
16.00 \\
15.40 \\
15.50\end{array}$ \\
\hline
\end{tabular}

Sources and Notes:

1. Base Case (Column A): Linear least squares best fit of residential energy consumption trends 1960-1972. The equation of the least squares fit: $Y=23.71+0.534 X_{\text {; }}$ Where $Y=$ residential energy consumption (quads), and $x=$ year (last two digits). Energy consumption data 1960-1972 from State Energy. Data Report DOE/EIA, September 1981.

2. Improved Bullding Shell Efficlency (To derive the raw bullding shell efficiency numbers, subtract Column B from Column A, 1.e., Column A - Column B): Data Prom analysis done by M.J. King, D.B. Belzer, et. al. of Pacific Northwest Laboratory "An Analysis of Changes in Residential Energy Consumption, 1973-1980," Draft Report, April 1982, pages 10-15.

3. Improved Appliance Efficiency (Column B - Column C): Data from M.J. King, D.B. Belzer, ct. al, pagcs 18-24.

4. Demographic Factors (Column C - Column D): Household migration data from M.J. King, D.B. Belzer, et. al, pages 16-17. Analysis of shifts to small households based on data fram Annual Housing Survey 1973-1980, Bureau of the Census. Shift measured by constructing a basellne of housing patterns holding 1973 housing patterns and energy use in each different type of housing unit constant. The baseline was then compared to actual housing patterns, keeping energy use constant, 1.e. Shift to small household = [Baseline (1973 household mix, constant energy use)] - [Actual household mix (constant energy use)].

5. Increased Use of Wood (Column D - Column E): Data from "Alternative Energy Data Sumnary for the United States," Resource and Technology Management Corporation, 1981.

6. Curtaliment Activities (Column E - Column F): Th1s is a residual, what remains after the other components of energy conservation have been accounted for. If there are other unmeasured components, they will also be in this residual. However, every affort has been made to include all significant components and, thus, this residual is belleved to rellably account for the effect of curtailment activities.

7. Actual Energy Use (Colum F): Data Prom State Energy Data Report, Energy Information

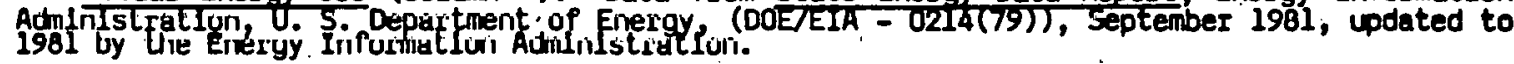


These points are not examined in Myths. In testimony before the Congress, Roger Sant acknowledged that there were some unsolved institutional obstacles to the achievement of economically attractive potential efficiency gains in the building sector, and he affirmed that imaginative enterpreneurs would find ways of dealing with them. $\underline{25}$ This issue is too important to EPC'S analysis and to the general subject of energy demand forecasting to be dealt with so casually.

The behavioral changes implicit in EPC's projections are of considerable magnitude, as shown in Table 8 . This table compares the proportions of capital and fuels as factors in the per-capita cost of energy services for 1378, 1990, and 2000. The dssumed discount rate of b\% (real) per year is favorable to investment, and the capital fraction rises by $32.9 \%$ in the building sector between 1978 and 2000 , and by $38.9 \%$ in the transportation sector over the same period. The capital fraction also increases in the industrial sector, but to a lesser extent (10.0\%). This indicates that the projected behavioral shifts are much larger for consumers than for industrial decisionmakers.

The increase in the capital fraction in all sectors is matched, of course, by a reduction in aggregate fuel consumption, but the market shares of the respective fuels are modified substantially. For all sectors, EPC's projections of consumption in 2000 by fuel type are shown (in comparison to other projections) in Table 5. As shown in both Table 5 and Table 8, consumption of conventional fuels (gas, oil, and electricity) is generally reduced in both the residential and commercial sectors, while coal and renewables increase slightly. The reduction in the use of conventional fuels is uneven, however: oil use is down sharply, both in comparison to 1978 and to EIA's ARC/79 forecasts for 2000; gas use is also down in both respects, though less dramatically; electricity use increases slightly in absolute terms between 1978 and 2000 , but well below that forecast in ARC/79.

In terms of space heating only, EPC projects a substantial increase in electricity's market share, as shown in Table 9. In terms of the percentage of dwellings served, both oil and gas decline, while electricity rises. In the commercial sector, the pattern is more complex: the oil share declines consistently through 2000 , while the gas share increases consistently through 2000; electricity's share increases through 1990 and then (for reasons not explained) declines in favor of gas through 2000. Myths i.s silent on the question of inter-fuel substitution in existing buildings, but EPC spokesmen affirm that measures such as the installation of heat pumps (either as replacements for worn-out oil or gas furnaces or as add-on units) were included in the modeling. If EPC's analysis were re-run with less optimistic assumptions about users' investment behavior, obviously the level of investments in energy-efficiency retrofits and equipment would decline, but the general direction of most of the trends would probably not be reversed.

25/Cf. transcript of Sant's testimony of Sept. 10, 1981 before the House Subcommittee on Energy Conservation and Power, Committee on Energy and Commerce, $\mathrm{pp} .44,55$. 
Table 8. Changing Proportions of Capital and Fuels as Factors in Per Capita Cost of Energy Services, as Projected by EPC

\begin{tabular}{|c|c|c|c|c|c|c|c|c|c|c|c|c|c|c|c|}
\hline \multirow[b]{2}{*}{ FACTOR } & \multicolumn{5}{|c|}{ BUILDINGS } & \multicolumn{5}{|c|}{ TRANSPORTATION } & \multicolumn{5}{|c|}{ INDUSTRIAL } \\
\hline & $\begin{array}{c}1978 \\
\text { fraction }\end{array}$ & I fraction & $\begin{array}{l}x \Delta \\
\text { from } \\
1978\end{array}$ & $1_{1}^{2000}$ & $\begin{array}{l}\text { x } \Delta \\
\text { from } \\
1978\end{array}$ & $\begin{array}{c}1978 \\
\text { fraction }\end{array}$ & n praction & $\begin{array}{l}\% \Delta \\
0 \text { from } \\
n \text { I } 1978\end{array}$ & $\begin{array}{l}1 \\
12000 \\
\text { fraction }\end{array}$ & $\begin{array}{l}* \Delta \\
\text { from } \\
1978\end{array}$ & $\begin{array}{c}1978 \\
\text { fraction }\end{array}$ & fraction & $\begin{array}{l}\text { \& } \Delta \\
\text { from } \\
1978\end{array}$ & $\left.\right|_{1} 2000$ & $\begin{array}{l}* \Delta \Delta \\
\text { from } \\
\text { n } 1978\end{array}$ \\
\hline Capital & .505 & $\begin{array}{ll}1 & .648 \\
1 & \end{array}$ & +28.3 & .671 & +32.9 & .422 & .513 & +21.6 & 1.586 & +38.9 & .458 & .470 & +2.62 & 21.504 & +10.0 \\
\hline Coal & .002 & .002 & 0.0 & $\begin{array}{l}1.003 \\
1.003\end{array}$ & +50.0 & -- & 1 & -- & 1 & -- & .027 & .049 & +81.5 & 1. & +151.9 \\
\hline 011 & .156 & 1.060 & -61.5 & 1.060 & -61.5 & .573 & 1.477 & -16.8 & .403 & -29.7 & .242 & .127 & -47.5 & 1. 118 & -51.2 \\
\hline Gas & .104 & . 077 & -26.0 & | .074 & -28.9 & .004 & 1.008 & +100.0 & .008 & +100.0 & .105 & .247 & +135.21 & 1.209 & +98.1 \\
\hline $\begin{array}{l}\text { Electricity } \\
\text { (ceritral static }\end{array}$ & $\frac{.234}{10 n}$ & .212 & -9.4 & 1.194 & -17.1 & .001 & .002 & +100.0 & 1.003 & +200.0 & .169 & $\begin{array}{l}1.107 \\
1 .\end{array}$ & $-36.7 !$ & 1.102 & -39.6 \\
\hline only & & & & $\begin{array}{l}1 \\
1\end{array}$ & & & 1 & & 1 & & & 1 & & 1 & \\
\hline Total & $1 . \infty$ & 11.00 & -- & 11.00 & -- & 1.00 & 11.00 & -- & 11.00 & -- & 1.00 & 11.00 & $\therefore$ & 1.00 & - \\
\hline
\end{tabular}

Notes

B. Source: Myths, pp. 24-27

b. Key assumptions: Macroeconomic assumptions (population growth, GN growth, etc.) from ARC/79; fuel price projections Prom ARC/79; cost of capital, 5x real per year. 
Table 9. Space Heating Market Shares by Fuel Type as Projected by EPC (Primary Heating Systems Only)

\begin{tabular}{|c|c|c|c|c|c|c|}
\hline \multirow{3}{*}{ Residential Units } & \multicolumn{2}{|c|}{1978} & \multicolumn{2}{|c|}{1990 Least Cost } & \multicolumn{2}{|c|}{2000 Least Cost } \\
\hline & housir & & $\begin{array}{r}\text { housing } \\
6\end{array}$ & & housing & \\
\hline & $\times 10$ & $\%$ & $\times 10$ & $\%$ & $\times 10$ & $\mathscr{x}$ \\
\hline gas & 46.3 & 62.7 & 53.7 & 58.2 & 59.6 & 57.5 \\
\hline oil & 16.2 & 21.9 & 11.7 & 12.7 & 10.9 & 10.5 \\
\hline electricity & 11.4 & 15.4 & $\underline{26.9}$ & 29.1 & 33.1 & 32.0 \\
\hline lotal & 73.9 & 100.0 & 92.3 & 100.0 & 103.6 & 100.0 \\
\hline
\end{tabular}

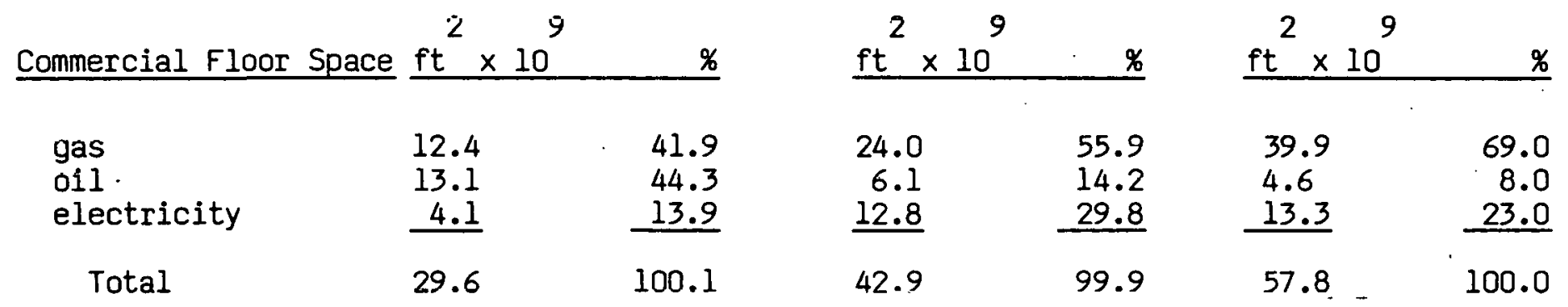

Source: Myths, p. 16. 
Iransportation Sector

The changes projected by EPC in the transportation sector are more easily. summarized. As shown in Tables 5 and 8, EPC's cost-conscious consumers invest heavily in more costly but more fuel-efficient vehicles, so that total consumption of petroleum products in the sector declines at an average annual rate of $-0.55 \%$ over the $1978-2000$ period, even though the total number of vehicles in use rises and total vehicle-miles traveled (VMT) rises. EPC estimates that average fuel economy for new cars sold in 2000 would be 51 MPG, measured on EPA's composite basis.6/ The investment. in fuel economy could raise the prices of those cars by $\$ 2000$ per car (in current dollars). 27/ The market shares: of electric- and natural gas-powered vehicles increase, but their portions of the overall market remain very small.

\section{Industrial Sector}

EP's treatment of the industrial sector, in contrast, has many obscurities. This sector is inherently more difficult to model and analyze than the others, because of its greater heterogeneity in terms of energy-using processes and products. To cope with this diversity, EPC used the ISTUM model, in which levels of industrial activity are specified as inputs by 2-digit SIC classifications; for each SIC group, moreover, a specified mix of energy service demands is established in relation to a given level of industrial output. Additional inputs to the model are required concerning future fuel prices and the capital costs associated with alternate technologies. With these inputs, the model then assesses the comparative economics of alternative technologies for satisfying the various energy service requirements, and selects the least-cost alternatives.

With this rich diversity of inputs and outputs, it is ironic and frustrating to find that EPC is largely silent in Myths on all but the grossest of projected changes in the industrial sector. As shown in Table 5, EPC provides figures on total consumption of various fuels within the sector, but there is very little detail in the text about the principal opportunities to use fuels more efficiently, what inter-fuel substitutions are to be expected, what SIC classes or industrial processes will be particularly affected, etc.

26/Ibid., p. 13.

27/Sent testimony of Sept. 10, 1981, p. 30 . 
Table 10 provides a more detailed look (than Table 5) at fuel use in the industrial sector in 2000, by comparing EIA's ARC/79 projections, EPC's projections, and some contemporaneous projections using the ISTUM model prepared by Energy and Environmental Analysis, Inc. (EEA).28/ All three of these analyses used EIA's ARC/79 fuel price trajectories, but EPC and EEA did not re-equilibrate fuel prices after making assumptions which caused demand for the various fuels to vary considerably from the pattern seen by EIA. Table 10 also includes for comparison more recent (February 1982) projections by EIA, which are based upon more current fuel price expectations.

Examination of Table 10 discloses some very interesting similarities and differences, particularly between the EEA and EPC figures. EPC, EEA, and EIA's ARC/79 are generally in agreement regarding projected coal use; EEA and EPC's numbers are virtually identical. EIA's ARC/81 figure for coal use is much lower, reflecting that expansion of coal use in the industrial sector is now appearing more problematic than believed in 1979 . Oil usage is down substantially in the EPC and EEA projections, in comparison to both EIA projections. EIA's ARC/81 oil use figure, in fact, is 2 quads higher than ARC/79, due principally to growth in petrochemicals production which more than offsets reduced fuel consumption. The 1.8 quad difference between EPC and EEA projections, however, is inexplicable, because their overall approach is so nearly identical. For renewables, the bulk of the activity is consistently in biomass, and there is much variance among the numbers, although again EPC and EEA have almost identical figures.

The projections for central-station electricity also show a lot of variance, again with substantial differences between EPC and EEA. EPC spokesmen attribute this in part to EPC's assumption of a higher penetration rate for high-efficiency motors. EIA's ARC/81 projection of central-station electricity demand is about $10 \%$ lower than its ARC/79 figure, reflecting the somewhat lower demand growth now generally antlclpated for this industry. Nevertheless, electricity's market share in the industrial sector is st1ll projected to increase, from about $11.6 \%$ in 1978 to about $14.6 \%$ in 2000 (calculated from figures shown in Table 5). Both percentages would be larger if feedstock consumption were netted out from total industrial energy use.

The projections for natural gas usage show particularly large differences, which are not altogether explainable. EEA and EPC have almost identical fiqures for gas consumption; moreover, they are very high in comparison to EIA's estimates, partly due to the favorable economic assumptions for gas-turbine cogeneration supplied to ISTUM, especially the relatively competitive price of deregulated gas (vs. central station electricity) from ARC/79. The 7.7 quad disparity between the EEA/EPC figures and EIA's ARC/79 estimate, however, cannot be explained only through increased cogeneration.

28/EEA's projections were prepared for EPC as inputs in the development of Myths. EEA's results are dependent upon critical assumptions specified by $\overline{E C}$ and should not be interpreted as EEA's best estimates of industrial energy demand. 
Table 10. Comparison of EIA, EPC, and EEA Projections of Energy Consumption in the Industrial Sector in 2000 (Quads)

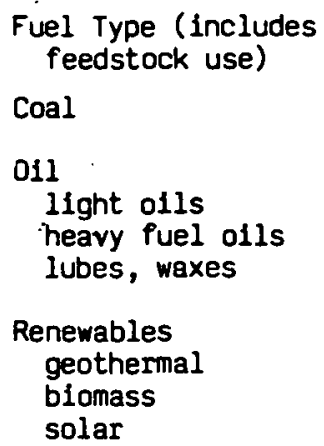

10.06
5.21

1.53

1.53

0.0

2.83

1.32

0.26

4.41

15.28

15.3

34.91
EEA d/

10.1

3.4

$$
?
$$

1.5

$1 . \overline{533}$

0.001

4.0

1.40

0.26

5.66

Notes

a. Energy Information Administration, Annual Report to Congress, 1979, v. III, Projections (DOE/EIA-0173(79)/3).

b. Energy Information Administration, 1981 Annual Report to Congress, v. III, Energy Projections (DOE/EIA-0173(81/3).

c. Mytlis, p. 18; fuel price liputs are also from ARC/79, and prices are not re-equilibrated after denand patterns change.

d. Energy and Environmental Analysis, Inc., unpublished ISTUM output dated Sept. 11, 1980, using assumptions specified by EPC. Fuel price 1nputs are from EIA's ARC/79, but prices are not re-equilibrated after demand patterns change.

e. Total consumption includes only fuels as obtained by the industrial sector. Hence, only electricity purchased from utilities is included in the total; cogeneration and autugeneration are accounted for elsewhere, according to the fuel used. Total electricity used by the sector, however, is shown as the sum of utilities' delivered output plus that from cogeneration and autogeneration. 
EPC says that 4.1 quads of gas would be used in cogeneration in $2000, \underline{29}$ / leaving an unexplained differential of 3.6 quads. Clearly, the anticipated boom in cogeneration is not the only major shift occurring in EPC's projections of industrial energy use.

Three comments are appropriate concerning EPC's use of ARC/79 gas price projections in an analysis published in 1981. First, as shown in Table 11, EIA's estimates of 1990 gas prices to industrial users have risen $21 \%$ in real terms since 1979; further, two recent studies published by DOE's Office of Policy, Planning and Analysis (PPA) show projected gas prices in the same range or higher. Second, there is disagreement among EPC, EIA, and PPA as to where deregulated gas prices will clear in relation to prices for petroleum products. That is, PPA believes that industrial users will bid gas prices up to a point just below that of residual oil, whereas EIA and EPC see gas clearing at a somewhat lower level in relation to oil. Third, while EIA and PPA may differ on question of the relationship between future oil and gas prices, they are in agreement that gas prices will rise significantly in relation to electricity prices.

According to a recent analysis published by $E I A, \underline{30 /}$ there are significant uncertainties on both the supply and demand sides of the gas price question. On the supply side, the issue is the quantity of gas likely to be available at low production cost. On the demand side there are several issues, principally: (1) whether there is a large latent demand for gas from industrial users who would prefer gas but are skeptical about long-term gas supply reliability; (2) the size of the cost premium industrial users are prepared to pay in order to avoid using coal; and (3) the rate at which natural gas (or methanol derived from it) could penetrate the transportation sector.

No attempt will be made to address those uncertainties here. However, it appears overly optimistic to assume, as in Myths, that gas prices will stay as low as projected in ARC/79 and that the gas industry will supply quantities as large as 23 quads (primary) annually in the 1990's.31/ EIA, for example, projected total annual domestic production in the 1990's in ranges of $16.5-19.0$ quads (ARC/79) and 18.0-18.5 quads (ARC/81). PPA projects a broader range, 16.1-22.4 quads, but at higher prices than those used by EPC. $\underline{32}$

29/Myths, p. 15.

30/An Analysis of Economic Effects of Accelerated Deregulaton of Natural Gas Prices (Energy Information Administration, Washington, D.C.: DOE/EIA-0303, August, 1981), pp. 8-13.

31/Myths, p. 7 .

32/Cf. ARC/79, v. III, pp. 126, 207; ARC/81, v. III, pp. 88, 174; Energy Projections to the Year 2000 , p. 6-2. 
Table 11. Comparison of Projected Prices for Selected Industrial Fuels in 1990 and 2000, as seen by EPC, EIA, and PPA (1979 \$/MiBtu)

\begin{tabular}{|c|c|c|c|c|c|}
\hline & \multirow[b]{2}{*}{$\underline{E P} \underline{\underline{a}}$} & \multicolumn{2}{|l|}{ EIA } & \multicolumn{2}{|c|}{$P P A$} \\
\hline & & $\underline{A R C / 79^{b} /}$ & $\underline{\operatorname{ARC} / 81}=$ & NEPP d/ & NGPA Study $\mathrm{e}^{\mathrm{e}}$ \\
\hline \multicolumn{6}{|l|}{1990 Inuustrial fuel Prices } \\
\hline \multirow{4}{*}{$\begin{array}{l}\text { natural gas } \\
\text { residual oil } \\
\text { distillate } \\
\text { sales-vgtd. avg. price for } \\
\text { resid. \& distillate combined } \\
\text { electricity (central station) } \\
\text { ratio of gas price to wgtd. avg. } \\
\text { price for petroleum derivatives } \\
\text { ratio of gas price to electricity } \\
\text { price }\end{array}$} & $\begin{array}{l}4.85 \\
6.22 \\
7.18\end{array}$ & $\begin{array}{l}4.85 \\
6.22 \\
7.18\end{array}$ & $\begin{array}{l}5.87 \\
8.17 \\
9.31\end{array}$ & $\begin{array}{l}6.68 \\
7.12 \\
8.90\end{array}$ & $\begin{array}{l}5.66 \\
5.98 \\
6.79 \text { I }\end{array}$ \\
\hline & $\begin{array}{r}6.99 \\
12.18\end{array}$ & $\begin{array}{r}6.99 \\
12.18\end{array}$ & $\begin{array}{r}8.66 \\
11.75\end{array}$ & $\begin{array}{l}8.469 / \\
12.69\end{array}$ & $6.599 /$ \\
\hline & 0.69 & 0.69 & 0.68 & 0.79 & 0.86 \\
\hline & 0.40 & 0.40 & 0.50 & 0.53 & - \\
\hline \multicolumn{6}{|l|}{$\underline{2000}$ Industrial Fuel Prices } \\
\hline $\begin{array}{l}\text { natural gas } \\
\text { residual oil } \\
\text { distillate } \\
\text { sales-watd. ava. price for }\end{array}$ & $\begin{array}{l}4.96 \\
7.15 \\
8.31\end{array}$ & $\begin{array}{l}4.96 \\
7.15 \\
8.31\end{array}$ & $\begin{array}{l}--h / \\
-- \\
--\end{array}$ & $\begin{array}{r}8.12 \\
9.46 \\
13.57\end{array}$ & $\begin{array}{l}--1 / \\
-- \\
-\end{array}$ \\
\hline \multirow{3}{*}{$\begin{array}{l}\text { sales-wg. \& distillate combined } \\
\text { resid. } \\
\text { electricity (central station) } \\
\text { ratio of gas price to wgtd. avg. } \\
\text { price for petroleum derivatives } \\
\text { ratio of gas price to electricity } \\
\text { price }\end{array}$} & $\begin{array}{r}7.98 \\
12.82\end{array}$ & $\begin{array}{r}7.98 \\
12.82\end{array}$ & $=$ & $\begin{array}{l}12.569 / \\
15.03\end{array}$ & $\overline{-}$ \\
\hline & 0.62 & 0.62 & -- & 0.65 & -- \\
\hline & 0.39 & 0.39 & -- & 0.54 & $\therefore$ \\
\hline
\end{tabular}

Notes

a. Myths, p. 47.

b. Energy Information Acministration, Annual Report to Congress, 1979, V. III, Projections (Washington, D.C.: DOE/EIA-0173(79)/3, 1979.

c. Energy Information Adninistration, 1981 Amual Report to Congress, v. III, Energy Projections (Washington, D.C.: DOE/EIA-0173(81)/3, 1982.

d. Energy Projections to the year 2000: A Supplement to the National Energy Plan (Washington, D.C.: U.S. DOE, DOE/PE-O029).

e. A Study of Alternatives to the Natural Gas Policy Act of 1978 (Washington, D.C., U.S. DOE, DOE/PE-0031).

f. PPA's study of alternatives to the NGPA did not publish distillate price projections. Here, distillate prices for 1990 have been estimated by preserving the same proportion between resid and distillate prices seen by EIA in ARC/80.

g. Ne1ther PPA study developed projections for consumption of distillate and resid. Here, consumption in the proportion projected by EIA in ARC/80 was assumed, enabling the derivation of a projected sales-wgtd, average price.

h. EIA'S ARC/81 does not Include price projections past 1995.

1. PPA's study of alternatives to the NGPA did not extend projections to 2000 . 
Perhaps the most distinctive feature of EPC's projections for the industrial sector is the very substantial growth in industrial cogeneration, particularly gas-turbine systems. In Myths, EPC does not provide figures for total installed cogeneration capacity projected for 1990 or 2000, total Kwh from cogeneration systems, or the expected mix of cogeneration capacity (i.e., coal-fired steam turbines, gas-turbines, diesels, etc.). However, it does assert that

[A] major trend is the installation of cogeneration units at new sites of major steam-consuming industrial firms. The most competitive cogeneration system is a gas-fired turbine that generates electricity, and then uses the waste heat from the turbine to make steam. 33 I

Further, EPC indicates that in 1990 and $2000,3.0$ quads and 4.1 quads, respectively, of gas would be used in cogeneration in the industrial sector. 34/ These levels of consumption imply installed capacities of approximately $38,000 \mathrm{MW}$ by 1990 and $53,000 \mathrm{MW}$ by $2000.35 /$ Finally, EPC implies that the growth in gas-turbine cogeneration is dependent upon the assumption of relatively low gas prices. They ran a sensitivity check using gas priced at the same level as oil and found that total national gas consumption (primary) dropped by 33\%, while central-station electricity rose by $30 \% .36$ The specific impacts upon cogeneration are not given but apparently they were severe.

Other analysts have surveyed the industrial landscape and found the outlook for gas-fired cogeneration much less promising. Paul Joskow, for example, reviewed the literature and concluded that where cogeneration is economically feasible, steam turbine systems using coal are generally the most economical choice. Diesel and gas fired systems are either uneconomical or are dominated by steam turbine systems fired by coal. 37!

33/Myths, p. 17 .

34/Ibid., p. 15.

35/EPC's Technical Appendix to The Least Cost Energy Strategy (1979) states $(p .25)$ that in gas turbine systems, 3.22 Btu of fuel will produce I Btu in the form of electricity (after which the exhaust gases may be used to raise steam containing $1.21 \mathrm{Btu}$ ). Using $1 / 3.22$ as a conversion ratio, gas consumed at the projected levels of cogeneration would yield 0.27 trillion $\mathrm{kwh}$ in 1990 and 0.37 trillion $\mathrm{kwh}$ in 2000. If the cogeneration systems functioned at 0.80 capacity factor, 38,000 Mw would be needed in 1990 and 53,000 $\mathrm{Mw}$ in 2000 to generate these quantities of electricity.

36/Myths, p. 41.

37/Paul L. Joskow, Industrial Cogeneration and Electricity Production in the United States, Massachusetts Institute of Technology, September 1981 (MIT-EL 81-06IWP), p. 30. 
Joskow also confirms that EPC's projected low gas price is likely to be the critical factor in their favorable assessment of gas-turbine systems:

Given prevailing price expectations it is extremely unlikely that an industrial firm can use oil in a steam turbine cycle and compete effectively with a utility burning much lower cost coal. Gas turbines and diesels could conceivably be economical, making up for the higher fuel costs with a higher electricity production rate. However, these technologies are extremely sensitive to uncertainties over future oil and gas prices because of their higher total heat rates. $\underline{38} /$

Ideally, one would like to be able to present EPC's assumptions and resultant costs for cogeneration -- in typical applications -- in comparison with analogous figures from other sources, in the manner shown in Table 12. This table compares the projected costs in 1990 of generating electricity in a new cogeneration facility and in a new conventional coal-fired plant; it also shows the projected cost to industrial users in 1990 of power purchased from the utility grid. The costs shown for electricity produced from the cogeneration facility are incremental costs -- that is, they do not include costs that would be incurred in a steam-only facility at the same site. The hypothetical cogeneration facility is designed for use in enhanced oil recovery in California, and the conventional coal-fired plant and purchasedpower cost estimates have been regionalized for the California/Arizona/Nevada area. Most of the data in the table come from EIA and Hagler, Bailly \& Co.; the EPC entries are largely blank. Nevertheless, the table yields some useful conclusions.

According to the Hagler, Bailly estimates (and as anticipated by Joskow) in an enhanced oil recovery application, a gas-fired cogeneration system can't compete economically with a new coal-fired utility unit. (The enhanced oil recovery case is important, because this industry has frequently been cited as having large amounts of cogeneration potential.) The Hagler, Bailly cogeneration system comes closer to competing with EIA's projected price for electricity from the grid, but this reflects the presence in the grid of a substantial amount of high operating cost oil- and gas-fired capacity. However, as modeled by EPC, the utility buy-back rate for electricity from cogenerators is $95 \%$ of the rate to industrial customers (or $57.7 \mathrm{mills} / \mathrm{kwh}$ in this example). Hence, the Hagler, Bailly cogeneration system would not be cost-effective under EPC's approach (although it might under the rules adopted by the California Public Service Commission, which assure higher buy-back rates to cogenerators). The disparity in cost/kwh between the new coal unit and the grid suggests that it may be advisable to build additional coal-fired capacity, as one (but not the only) means of reducing long-term costs to ratepayers.

38/ Ibid., p. 12 . 
Table 12. Costs of Generating vs. Buying Electricity in Callfornia in 1990, Accorjing to Projectlons by EPC, EIA, and Hagler; Bailly \& Co. (1981 \$)

\begin{tabular}{|c|c|c|c|c|c|}
\hline \multirow{2}{*}{$\frac{\text { Cost Component }}{\text { Capital }}$} & \multicolumn{2}{|c|}{ EPC Estimates } & Hagler, Bailly Estimate & \multicolumn{2}{|c|}{ EIA Est1mates } \\
\hline & $\begin{array}{l}\text { Cost of electr:city } \\
\text { Prom new gas turbine, } \\
\text { cogeneration system - }\end{array}$ & $\begin{array}{l}\text { Cost of } \\
\text { electricity } \\
\text { Prom utility griog/ }\end{array}$ & $\begin{array}{l}\text { Cost of electrlcity } \\
\text { from new gas turbine, } \\
\text { cogeneration system }\end{array}$ & $\begin{array}{l}\text { Cost of } \\
\text { electricity fyom } \\
\text { utility grid }\end{array}$ & $\begin{array}{l}\text { Cost (to utility) } \\
\text { of electricity from } \\
\text { new coal-fired plant- }\end{array}$ \\
\hline $\begin{array}{c}-p 1 \times e d \\
\$ / k w \\
\text { cost }\end{array}$ & $?$ & NA & 499?! & NA & 1109 \\
\hline $\begin{array}{l}\text {--annuallzed } \\
\text { P1xed cost, } \\
\text { m1lls/kwh }\end{array}$ & $?$ & MA & 7.7 & NA & 18.6 \\
\hline Fuel & & & & & \\
\hline$--\$ /$ MABtu & 6.64 & NA & 6.76 & NA & 2.32 \\
\hline$--m i l i s / k w h$ & $?$ & NA & 60.0 & NA & 22.5 \\
\hline QLM & & & & & \\
\hline$--m 111 s / k w h$ & $?$ & NA & 0.6 & NA & 7.3 \\
\hline $\begin{array}{l}\text { Total cost } \\
\text { In } \mathrm{m} 1 \mathrm{ll} / \mathrm{s} / \mathrm{kwh}\end{array}$ & $\bar{?}$ & $\overline{63.6}$ & $\overline{63.3}$ & $\overline{60.5}$ & $\overline{48.4}$ \\
\hline
\end{tabular}

Notes

a. All EPC entries are unknown except for the ges fuel price, which has been taken from ARC/79, converted to $1981 \$$, and adjusted for seglo $2 a 1$ variation per unpublished EA pro.'ections dated 12/17/81.

b. EPC does not meed to estimate utility costs because they are modeling the Industrial decisionmaker's choices between buying electricity from the gr:d at the price shown and bullding a cogeneration system. Hence the only relevant datum is the g:id's price, which is taken Prom ARC/79, converted to 1981 \$, and adjusted for reglonal veriation per unpublished EIA projections dated $12 / 27 / 81$.

c. This hypothet: zal cogeneration system would be used in enhanced ofl recovery (三OR) applications. The gas turbine/waste heat boller is sized at a steam capacity of $200,000 \mathrm{lb} . / \mathrm{hr}$., and is Jperated at 0.80 capacity Pactor. Large: systems would produce lower-cost electr-city, but $200,000-250,000 \mathrm{Ib} . / \mathrm{hr}$. 15 the maximun pract1cal s1ze for most EOR applications 17 California. Lasts shown are incremental costs -- that is, they do not include any of the costs that would be incurred in a steam-only facility at the same site. [(See An Assessment of the Costs of Producing Cogenerated would be incurred in a steam-only facility at the same site. [(See An Assessment ji the Costs of Producing
Electr1c1ty in the Enhanced 01: Recovery Industry (Washington, D.C.: Hagler, Bailly \& Co., March 1982).]

d. Unpublished EIA price projections, dated $12 ; 17 / 81$.

e. Fuel used is low sulfur bituminous coal, 12,000 Btuilb.; data from unpublished naterlals related to ARC/80.

f. Excludes interest during construction. 
EPC's price for electricity from the grid is somewhat higher than EIA's 1981 price, but this reflects the earlier vintage of the ARC/79 prices used by EPC. An EPC estimate of the cost/kwh for electricity from the cogeneration facility is obviously not available. However, it is also clear that EPC believes that in many applications, cogeneration will be able to compete effectively with the grid price. The disparity between the Hagler, Bailly and EPC estimates of the price of gas to the prospective cogenerator is significant and it is reasonable to assume that it is a major factor in the different conclusions reached by EPC and other analysts.

Two additional points remain concerning EPC's treatment of the industrial sector. First, as shown in Figure 2 and Table 13, recent reductions in expected energy use in the industrial sector have been due more to slower economic growth and shifts in the composition of industrial output than to efficiency improvements. This suggests that, as in other sectors, substantial improvements remain to be made, and that the rate of adjustment is considerably slower than that projected by EPC. Second, EPC's expectation that enterpreneurs will finance and deliver needed retrofits to users in return for a share of the fuel cost savings appears to be somewhat more viable in some parts of the industrial sector than elsewhere, although the scope of these markets remains unclear. 39 I

V. Implications of MYTHS for the Electric Utility Industry

As previously noted, EPC modeled only end-use decisions, and therefore had no occasion to address the question of the need for additional central-station power plants, whether to meet demand growth or to replace worn or economically obsolete units. However, EPC does provide projections of future electricity demand, and it is worthwhile to assess their plausibility and to draw whatever inferences from them seem most appropriate.

EPC's projections of demand for utility-supplied electricity are shown in Table 14, by sector and in comparison with similar projections from EIA and PPA. The table shows both projected consumption (in quads) and average annual growth rates for the periods 1978-1990 and 1990-2000. As one might expect, EPC's demand growth rates are generally lower than the others. There are, however, some interesting sectoral and chronological variances which warrant examination.

For example, demand growth is reduced more sharply in the industrial sector than in the residential and commercial sectors. Compared to EIA's ARC/79 forecast for the 1978-1990 period, EPC reduced electricity demand growth in the industrial sector from $4.5 \%$ per year to $-1.0 \%$ per year. In the residential sector, growth drops fom $2.2 \%$ per year to $0.0 \%$; in the commercial sector, from $2.6 \%$ to $0.5 \%$. The same pattern, somewhat softened, appears for

39/The size of these markets is sensitive to changing Federal tax provisions. See "Tax Scheme Threatens Shared-Savings Jobs," Energy User News, April 12, 1982, p. 1. For a more general discussion, see H. Christopher Peterson, Energy Management Systems: An Industry Appraisal (unpublished DOE staff paper, August 1980). 


\section{Energy Trends in Industry}

\section{ENEFGY USE}

(quads)

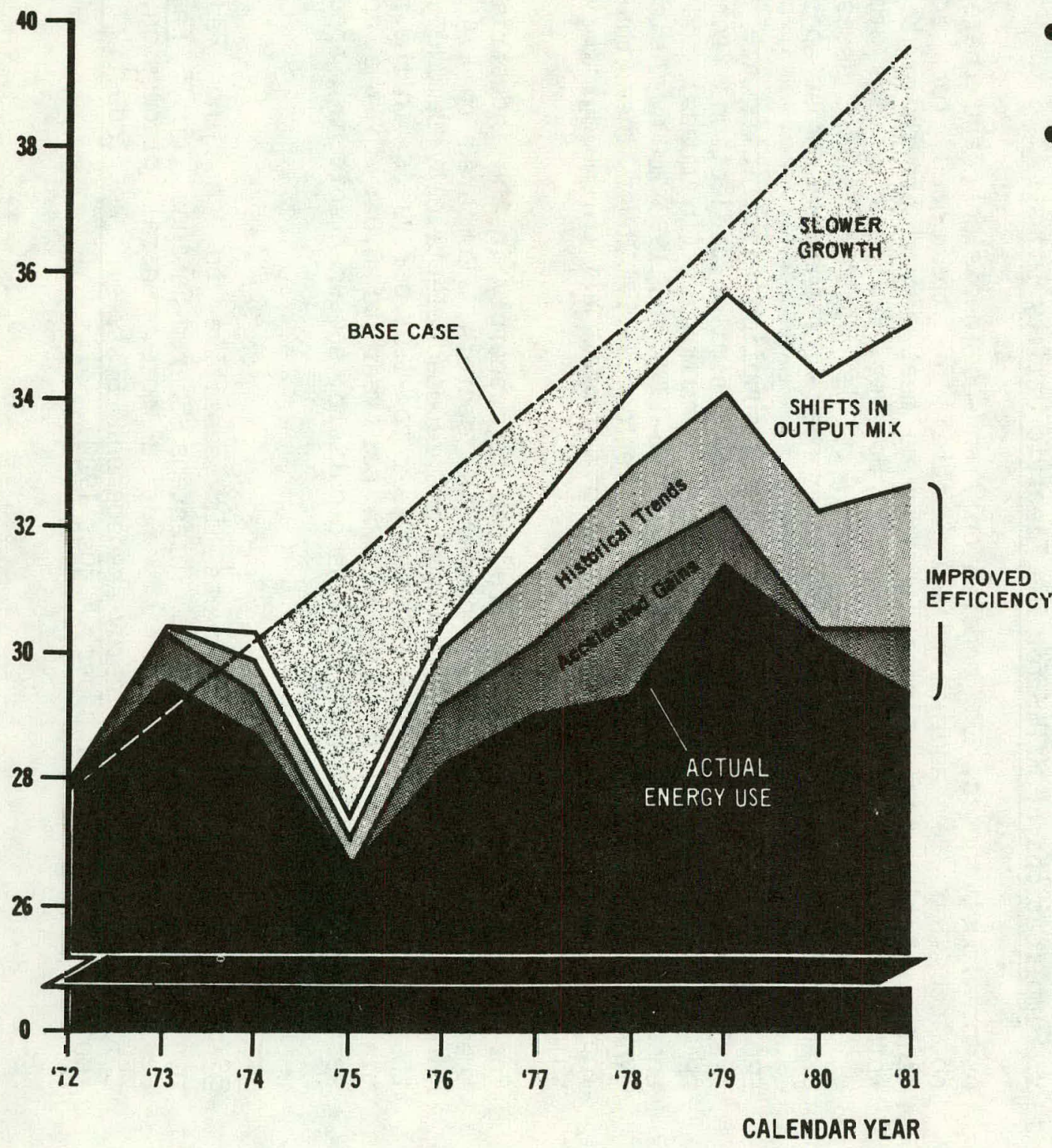

- ENERGY USE in 1981 was down 10.4 quads from the base case.

- These ENERGY SAVINGS (26\%) result from several factors:

- SLOWER GROWTH (4.4 quads) .... industrial output slowed from $4.0 \%$ per year to $2.6 \%$ per year after 1972 ;

- SHIFTS IN OUTPUT MIX (2.6 quads) ... depressed output among large energy using industries (steel, cement, chemicals, aluminum, paper) is offset by increased growth in lighter manufacturing (textiles, fabrication of aircraft and machinery parts, computers, and food processing);

- IMPRDVED ENERGY EFFICIENCY (3.4quads)... new technologies and better energy management. Part is due to the HISTORICALTRENDS(2.3 quads) in improving energy efficiency associated with capacity expansion and capital stock turnover; the remainder is due to ACCELERATED GAINS (1.1 quad) in improved efficiency associated with higher energy prices.

Source: R. Marlay, Office of Po icy, Planning, and Analysis, U.S. Department of Energy. Analysis besed on data from the Board of Governors of the Federal Reserve System, the US. Department of Commerce the Energy Information Administration, and on "Industrial Energy Productivity, 1954-1950," Massachusetts Institute of Techno logy. Cambridge, M.A. 
Table 13. ENERGY TRENDS IN INOUSTRY

(Energy Use in Quads)

\begin{tabular}{|c|c|c|c|c|c|c|c|c|}
\hline Year & $\begin{array}{l}\text { Basel } \\
\text { Case } \\
E_{1}\end{array}$ & $\begin{array}{c}\text { FRB }^{2} \\
\text { Index } \\
M+M\end{array}$ & $\begin{array}{c}\text { Output } 3 \\
\text { Adjusted } \\
\mathrm{E}_{2}\end{array}$ & $\begin{array}{c}\text { Shift } 4 \\
\text { Factor } \\
f_{s}\end{array}$ & $\begin{array}{c}\text { Adjusted } 5 \\
\text { for Shift } \\
E_{3}\end{array}$ & $\begin{array}{l}\text { Tech6 } \\
\text { Trend } \\
\text { Factor } \\
\text { fT }\end{array}$ & $\begin{array}{c}\text { Adjusted } \\
\text { for } \\
\text { Historical } \\
\text { Trends } \\
E_{4}\end{array}$ & $\begin{array}{c}\text { Actual } \\
\text { Energy } \\
\text { Use } \\
\text { E }_{5}\end{array}$ \\
\hline $\begin{array}{l}72 \\
73 \\
74 \\
75 \\
76 \\
77 \\
78 \\
79 \\
80 \\
81 p\end{array}$ & $\begin{array}{l}27.9 \\
29.0 \\
30.2 \\
31.4 \\
32.7 \\
34.0 \\
35.3 \\
36.7 \\
38.2 \\
39.7\end{array}$ & $\begin{array}{l}118.5 \\
128.8 \\
128.4 \\
116.1 \\
128.2 \\
137.0 \\
145.3 \\
151.7 \\
145.8 \\
149.8\end{array}$ & $\begin{array}{l}27.9 \\
30.4 \\
30.3 \\
27.4 \\
30.4 \\
32.3 \\
34.2 \\
35.7 \\
34.4 \\
35.3\end{array}$ & $\begin{array}{l}1.000 \\
0.998 \\
1.014 \\
1.014 \\
1.010 \\
1.029 \\
1.036 \\
1.048 \\
1.066 \\
1.080\end{array}$ & $\begin{array}{c}27.9 \\
(30.5) \\
29.9 \\
29.9 \\
30.1 \\
31.4 \\
33.0 \\
34.1 \\
32.3 \\
32.7\end{array}$ & $\begin{array}{l}1.000 \\
1.008 \\
1.016 \\
1.024 \\
1.032 \\
1.041 \\
1.049 \\
1.057 \\
1.066 \\
1.074\end{array}$ & $\begin{array}{c}27.9 \\
30.3 \\
29.4 \\
(26.4) \\
29.2 \\
30.2 \\
31.5 \\
32.3 \\
30.3 \\
30.4\end{array}$ & $\begin{array}{l}27.9 \\
29.5 \\
29.7 \\
26.5 \\
28.2 \\
29.0 \\
29.3 \\
31.4 \\
30.2 \\
29.3\end{array}$ \\
\hline
\end{tabular}

\section{Sources and Notes:}

1. Base case industrial energy use, El, is developed by extrapolating 1972 industrial sector energy use ( 27.923 quads; see Note 8 ) at an average annual growth rate of 4.0 percent per year. This growth rate assumes constant 1972 base year efficiencles per unit of industrial sector output and a historical growth rate of industrial output of 4.0 percent per year, which equals that for the 1953-1972 period, as measured by the Federal Reserve Board's index of industrial production for mining and manufacturing (excluding gas and electric utilities). The FRB's indexes for 1953 and 1972 are 56.3 and 118.5 respectively.

2. Data for the Federal Reserve Board's Index of industrial production for mining and manufacturing for the years 1972 through 1981 are from the Economic Report of the President, January 1981 and from Industrial Production, Publication G.12.3, Board of Governors of the Federal Reserve System, March 16, 1982.

3. Energy use adjusted for changing industrial output, $E_{2}$, assumes constant 1972 base year energy efficiencies per unit of industrial output and is developed by scaling 1972 industrial sector energy use (27.923 quads) by the FRB index for mining and manufacturing.

4. The shift factor, $P_{S}$, is a cumulative measure of structural shifts in the $m i x$ of Industrial output either toward or away from energy consumptive industrles. It is derived by comparing the annual increases or decreases in two aggregate measures of industrial production for 472 mining and manufacturing industries. The first is a value-added weighted index. The second is an energy consumption welghted index. The underlying data on industrial production are from the Census of Manufacturing and Mineral Industries, U.S. Department of Commerce, and Industrial Production, Federal Reserve Board. A more detailed analysis of this phenomena is presented in a paper in process by $R$. Marlay, entitled "Industrial Energy Productivity, 1954-1980," researched at the Department of Nuclear Englneering, Massachusetts Institute of Technology, while on leave of absence from the U.S. Department of Energy.

5. Energy use adjusted for shift away from energy consumptive Industries, $E_{3}$, is developed by dividing $E_{2}$ by $f_{s}$.

6. The technological trend factor, $P_{T}$, is developed by observing the apparent and improving trend in energy use per unit of industrial output (energy welghted index) from 1954 through 1972. This trend, revealed in a period of declining real energy prices, is observed to be about 0.8 percent per year, and is assumed to continue at the same rate in the post-1972 period.

7. Industrial sector energy use, as adjusted further for the continuation of historical trends in the improvement in energy efficiency, $E_{4}$, is developed by dividing $E_{3}$ by $f_{T}$.

8. Actual Industrial sector energy use, E5, Is from the Annual Report to Congress, Volume 2. 1980, and the Monthly Energy Review, March 1982, both from the Energy Information Administration, U.S. Department of Energy. 
Table 14. Projected Demand Growth for Central-Station Electricity, 1990 and 2000 (By Sector). According to EPC, $\underline{a} / \mathrm{EIA}, \underline{\mathrm{b}} /$ and $\mathrm{PPA}$ /

\begin{tabular}{|c|c|c|c|c|c|}
\hline \multirow[b]{2}{*}{ Sector } & \multirow[t]{2}{*}{$\begin{array}{c}1978 \\
\text { Consumption } \\
\text { (Quads) } \\
\end{array}$} & \multirow[t]{2}{*}{$\begin{array}{c}\text { Average } \\
\text { Annual Growth } \\
\text { Rate (\$) } \\
\end{array}$} & \multirow[t]{2}{*}{$\begin{array}{c}1990 \\
\text { Consumption } \\
\text { (Quads) }\end{array}$} & \multirow[t]{2}{*}{$\begin{array}{l}\text { Average } \\
\text { Annual Growth } \\
\text { Rate (x) } \\
\end{array}$} & \multirow[t]{2}{*}{$\begin{array}{c}2000 \\
\text { Consumption } \\
\text { (Quads) }\end{array}$} \\
\hline & & & & & \\
\hline $\begin{array}{l}\text { Residential } \\
\text { EPC } \\
\text { EIA }\end{array}$ & 2.4 & 0.0 & 2.4 & -0.4 & 2.3 \\
\hline $\begin{array}{l}\text {-ARC/79 } \\
\text { PPA ARC/81 } \\
\text { PPA }\end{array}$ & $\begin{array}{l}2.4 \\
2.4 \\
2.4\end{array}$ & $\begin{array}{l}2.2 \\
1.9 \\
1.6\end{array}$ & $\begin{array}{l}3.1 \\
3.0 \\
2.9\end{array}$ & $\begin{array}{l}0.9 \\
2.7 \\
1.6\end{array}$ & $\begin{array}{l}3.4 \\
3.9 \\
3.4\end{array}$ \\
\hline $\begin{array}{l}\text { Commercial } \\
\text { EPC } \\
\text { EIA }\end{array}$ & 1.7 & 0.5 & 1.8 & 1.6 & 2.1 \\
\hline $\begin{array}{l}\text {-ARC/73 } \\
\text { PPA }\end{array}$ & $\begin{array}{l}1.7 \\
1.7 \\
1.7\end{array}$ & $\begin{array}{l}2.6 \\
2.9 \\
2.6\end{array}$ & $\begin{array}{l}2.3 \\
2.4 \\
2.3\end{array}$ & $\begin{array}{l}U .8 \\
1.9 \\
2.4\end{array}$ & $\begin{array}{l}2.5 \\
2.9 \\
2.9\end{array}$ \\
\hline $\begin{array}{l}\text { Industrial } \\
\text { EPC }\end{array}$ & 2.7 & -1.0 & 2.4 & 1.6 & 2.8 \\
\hline $\begin{array}{l}\text {-ARC/79 } \\
\text { PPA }\end{array}$ & $\begin{array}{l}2.7 \\
2.7 \\
2.7\end{array}$ & $\begin{array}{l}4.5 \\
3.1 \\
4.2\end{array}$ & $\begin{array}{l}4.6 \\
3.9 \\
4.4\end{array}$ & $\begin{array}{l}2.3 \\
2.9 \\
3.2\end{array}$ & $\begin{array}{l}5.8 \\
5.2 \\
6.0\end{array}$ \\
\hline \multicolumn{2}{|c|}{$\begin{array}{l}\text { Total (incl. transportation, } \\
\text { nnt. shnwn Ahnve) }\end{array}$} & & & & - \\
\hline $\begin{array}{l}E P C \\
\text { EIA }\end{array}$ & 6.8 & -0.2 & 6.6 & 1.0 & 7.3 \\
\hline $\begin{array}{l}-=A R C / 79 \\
-=A R C / 81 \\
\text { PPA }\end{array}$ & $\begin{array}{l}6.8 \\
6.8 \\
6.8\end{array}$ & $\begin{array}{l}3.3 \\
2.6 \\
2.9\end{array}$ & $\begin{array}{r}10.0 \\
9.3 \\
9.6\end{array}$ & $\begin{array}{l}1.6 \\
2.1 \\
2.5\end{array}$ & $\begin{array}{l}11.7 \\
12.0 \\
12.3\end{array}$ \\
\hline
\end{tabular}

Notes

a. Myths, pp. 14-15; Myths' "bulldings" sector divided here into residential and commercial on the basis of unpublished information provided by EPC.

b. EIA's projections are from Annual Report to Congress, 1979, v. III, Projections (Energy Information Administration, Washington, D.C.: DOE/EIA-0173(79)/3, 1979); and 1981 Annual Report to Congress, v. III, Energy Projections (Energy Information Administration, Washington, D.C.: DOE/EIA-0173(81)/3, 1982).

c. PPA's projections are from Energy Projections to the Year 2000: A Supplement to the

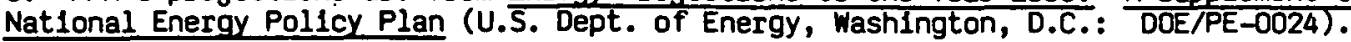


the 1990-2000 period. That is, although the reductions in demand growth are generally smaller than in the 1980's, the reduction in the industrial sector is still larger than in the other two sectors. These results are not altered much if one uses the ARC/81 and PPA figures for comparison with EPC's, instead of ARC/79.

As seen in the preceding section, EPC's reduction in electricity demand in the residential and commercial sectors results from projected improvements in the thermal integrity of existing buildings, market penetration by energyefficient appliances, construction of energy-efficient new buildings, and upgrading of existing HVAC equipment. The pace at which these improvements are made is substantially accelerated by EPC's assumptions about users' energy investment behavior.

In the industrial sector, however, it is far less clear what adjustments and substitutions lead to such large-scale shifts in demand. The projected boom in gas-fired cogeneration is a major element, but only that. EPC says that 3.0 and 4.1 quads of gas will be used in 1990 and 2000 , respectively, for cogeneration; the electricity outputs would be approximately 0.9 and 1.3 quads. If one assumes that this cogeneration did not occur and that the same amount of electricity were supplied by utilities, industrial demand growth would rise from $0.2 \%$ per year to $1.9 \%$, for the $1978-2000$ period -- as compared to EIA's ARC/79 figure of $3.5 \%$ per year. Further, while EPC shows electricity demand growing at $0.2 \%$ per year for $1978-2000$, gas demand grows at 2.7\%. After deducting the gas used in cogeneration, industrial gas demand still grows at $1.3 \%$ per year.40/ Apparently, the same assumed low gas prices wich make gas-fired cogeneration economic also stimulate other industrial shifts from electricity to gas.

Much of the reduction in electricity demand foreseen by EPC occurs in the 1980 's, as opposed to the 1990's. This can be seen readily in Table 14, but the trend is not specific to electricity. Energy users in the 1980's are preoccupied with both retrofits and the purchase of new capital stock which is energy efficient. By the 1990's, most of the inefficient stock has either been retrofitted or scrapped. Reduction in demand (and also shifts in market shares among competing fuels) then occurs largely through users' purchases of new capital stock which is highly energy-efficient.

Overall; these results concerning timing appear implausible and are presumably determined by EPC's modeling assumptions. EPC's treatment of energy users' decisionmaking obviously tends to accelerate the projected transitions, but there may be other contributing factors as well. In general, one can think of many conditions and problems which.will retard adjustment processes, such as lack of access to capital for many users, the need to develop a large and qualified infrastructure, and disjunction of interests between owners and occupants of rental housing and much commercial floor space.

40/Annuel demand growth rates finr gas calculated from data presented in Table 5. 
If one takes EPC's electricity demand growth projections at face value, their implications are straightforward. If demand growth for 1978-1990 occurs at $-0.2 \%$ per year, and at $1.0 \%$ per year for $1990-2000$, the nation has little need for additional generating capacity. Plants now under construction and scheduled for completion during the 1980's would be more than ample to replace worn-out equipment; the excess would provide a cushion for meeting the resumption of modest demand growth in the 1990's. Further, under EPC's assumptions, the need to replace many existing units with more economic new plants would probably be greatly reduced. With EPC's gas prices, it would probably not be economically desirable to replace existing gas-fired baseload plants. Existing oil-fired plants could be converted to gas, or at greater expense, to coal. (EPC refers cryptically to electric utility investments of $\$ 10$ billion/year in the 1980's and $\$ 19$ billion/year in the 1990's (1979 \$), but the nature of these investments is not explained. $4 \underline{41}$

Thus, the central question becomes: Should EPC's projections of electricity demand be regarded as reliable? The answer is no. At least five major points of concern have been identified: the low gas prices, unrealistic assumptions about users' investment behavior, the lack of detail about major changes in the industrial sector, the need for typical examples of economically attractive gas-fired cogeneration projects, and the projected rapid optimization of capital stock in the 1980's. Others might well surface if EPC's models and assumptions could be examined in detail.

Moreover, EPC's results appear to lack what modeling technicians call "stability" or "robustness." That is, it appears that if one were to modify some of their key parameters (by using more recent fuel price projections and a more realistic treatment of users' investment behavior) one would get rather different and more conventional results for electririty demand--and by Implication, the need for additional generating capacit.y. Conceptually, EFC's work is original and important, but the execution has critical flaws.

4l/Myths, p. 32; also see Table 3 above. 


\section{UNITED STATES}

DEPARTMENT OF ENERGY

WASHINGTON, D.C. 20585

OFFICIAL BUSINESS

PENALTY FOR PRIVATE USE, $\$ 300$
POSTAGE AND FEES PAID

U.S. DEPARTMENT OF ENERGY

DOE 350

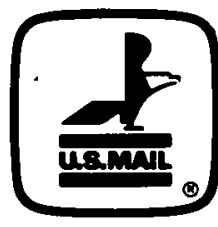

THIRD CLASS MAIL 